\title{
Poder Legíslativo Política Externa: Um Estudo sobre a Influência do Congresso Nacional do Chile na Formulação da Política Comercial durante a Década de 1990*
}

Flávio Leão Pinheiro**

\section{Introdução}

$(0$ objetivo deste estudo é avaliar se o Poder Legislativo detém influência sobre a política externa, tendo como base o envolvimento do Congresso Nacional do Chile no processo decisório da política comercial durante a década de 1990. O senso comum indica que temas relacionados à política exterior estão restritos ao Poder Executi-

\footnotetext{
*Artigo recebido em junho e aprovado para publicação em agosto de 2007.

**Mestre em Ciência Política pelo Instituto Universitário de Pesquisas do Rio de Janeiro (Iuperj) e professor do curso de Pós-graduação Lato Sensu em nível de especialização (MBA) em Diplomacia e Negócios Internacionais da Argus/UniverCidade. E-mail: pinheiro.f@gmail.com.
} 
vo. Essa percepção aumenta quando diz respeito aos países latino-americanos, já que a região ficou estigmatizada pelo recente passado autoritário e pelo presidencialismo forte, que emergiu das cartas constitucionais democráticas das últimas décadas. No entanto, mesmo analisando um país considerado por grande parte da literatura institucionalista um caso extremo na América Latina, no que diz respeito aos poderes presidenciais (CAREY; SHUGART, 1992; VALENZUELA, 1998; MAINWARING; SHUGART, 1997a; 1997b; SIAVELIS, 2000), o resultado da pesquisa aponta para outra direção: o Legislativo é um importante ator político no processo de formulação da política comercial chilena.

O ponto de partida para a investigação é o debate travado na literatura de Relações Internacionais a respeito dos determinantes políticos da política externa. Ele esteve invariavelmente marcado pelo predomínio da visão realista, fato que contribuiu para marginalizar enfoques que conferiam maior atenção a variáveis domésticas, pois o realismo está amparado em premissas que dificultam esse tipo de abordagem ${ }^{1}$ (GERNER, 1995; HILL; LIGHT, 1985; SMITH, 1986). De forma objetiva, e incorrendo no risco da simplificação, pode-se dizer que tais premissas são: a centralidade do Estado, a ênfase nas relações de poder e a percepção de que a anarquia é uma característica inerente à esfera internacional (MORGENTHAU, 1951; KENNAN, 1984; WALTZ, 1996). Desde o final da década de 1980, no entanto, há um maior número de trabalhos que utilizam variáveis domésticas para explicar a atuação dos Estados no cenário internacional, dialogando com realistas clássicos, neo-realistas e neoliberais.

A partir do marco teórico apresentado pelos internacionalistas institucionalistas (PUTNAM, 1988; MILNER, 1997; MARTIN, 2000) e a par das constatações feitas por novos estudos legislativos sobre a América Latina - mais especificamente sobre o Chile -, que procuram questionar o estereótipo do Legislativo como instituição marginal no processo decisório, apresentando argumentos consistentes de 
que, apesar de o Executivo deter amplos poderes constitucionais, o Legislativo tem, progressivamente, aumentado sua capacidade de influenciar o processo decisório de políticas públicas, foi possível formular hipóteses teóricas para o presente estudo.

Acredita-se que a contribuição deste trabalho é válida não só para o caso chileno, mas para estimular novos estudos sobre outros países da região, pois está calcado em questionamentos relegados por boa parte das análises a respeito de integração regional e de política externa latino-americana: qual o grau de complexidade da tomada de decisões de política externa, sob a ótica doméstica? O Legislativo pode ser considerado um ator político em matéria de política externa ou está alijado do processo decisório?

O artigo está organizado da seguinte forma: a primeira parte traz uma breve apresentação da abordagem teórica e discute as relações entre o Executivo e o Legislativo no Chile. Em seguida, apresenta as hipóteses que serão testadas na parte final. Na segunda parte, são expostos os dispositivos constitucionais que regulam a ação do Executivo e do Legislativo no processo decisório da política comercial. Por fim, as hipóteses desenvolvidas na primeira parte são testadas diante de estudo de caso que envolve a participação do Congresso Nacional do Chile na implementação dos Acordos de Complementação Econômica (ACEs) e no processo de abertura unilateral da economia - redução tarifária - durante a década de 1990.

É importante ressaltar que são realmente bastante escassos os trabalhos que buscam avaliar a influência parlamentar em matéria de política externa - e política comercial. Conforme se constatou, não há estudos específicos. ${ }^{2}$ No que diz respeito à literatura sobre política comercial, na maior parte dos casos, não há menção ao papel exercido pelo Poder Legislativo. Nos poucos estudos que mencionam e tratam do tema, quase sempre é conferida à instituição a função de mero espectador do processo decisório. 


\section{A Metáfora do Jogo de Dois Níveis e o Poder Legislativo}

Em "Diplomacy and domestic politics: the logic of two-level games", Robert D. Putnam (1988) busca explicar a cooperação entre os Estados levando em consideração tanto o nível doméstico quanto o internacional. Assim, em sua concepção, o modelo de análise para compreender a dinâmica entre a diplomacia e a política doméstica é o jogo de dois níveis. No nacional (Nível II), estão os grupos de interesse, partidos políticos, burocratas etc., que pressionam negociadores e buscam construir coalizões para impor suas preferências; enquanto no internacional (Nível I), encontram-se os governos nacionais, que buscam atender, dentro do possível, às demandas internas perante outros governos. No Nível I, portanto, há a negociação do acordo, enquanto o Nível II é a esfera que vai avaliar se o acordo pode ser aceito ou não.

Durante o processo de ratificação ${ }^{3}$ empreendido no Nível II, a lógica que prevalece é a de que só se pode acolher ou vetar por inteiro o acordo alcançado no Nível I, uma vez que emendas acarretariam na reabertura das negociações no Nível I. Em face dessas condições, torna-se fundamental a determinação da estrutura de ganhos domésticos (win-set) dos atores do Nível II no processo de interação dos dois níveis, já que tal estrutura ditará as condições das negociações no contexto externo. A determinação do win-set no modelo do jogo de dois níveis é, pois, essencial, e vai depender da dinâmica de três variáveis domésticas que Putnam (1988) apresenta: preferências e coalizões; instituições; e a estratégia do negociador. Vale ressaltar que, para além da apresentação da causalidade doméstica para explicar a política externa dos Estados, a novidade apresentada pelo autor diz respeito à relevância da ratificação das obrigações contraídas no exterior no plano doméstico. 
Uma série de estudos recentes utiliza a metáfora dos jogos de dois níveis para se pensar o peso de fatores domésticos sobre a cooperação internacional. Dentre eles, destaca-se o trabalho de Lisa Martin (2000), Democratic commitments - legislatures and international cooperation, cujo principal objetivo é explicar os compromissos internacionais dos Estados por meio de determinantes políticos domésticos, no caso, a atuação do Poder Legislativo. Procura-se, assim, responder a duas questões: primeiro, os Legislativos nacionais influenciam o processo decisório da política externa? Ou seja, as preferências dos legisladores são levadas em conta? Em segundo lugar, caso influenciem, quais as conseqüências? (MARTIN, 2000, p. 13).

Com base em elementos da literatura sobre organização legislativa, interação entre Executivo e Legislativo, e credible commitment, Martin estrutura um modelo de análise que resulta nas seguintes conclusões. O grau de influência do Legislativo nos processos de cooperação internacional excede à percepção comum - tal influência é mais profunda e sutil. O Legislativo pode delegar poderes ao Executivo para este negociar com outros países, mas permanece com capacidade para interferir no processo. Sobre as consequiências, o principal resultado da interação institucionalizada dos Legislativos é um maior comprometimento do país com os compromissos assumidos no exterior, apontando para padrões mais estáveis de cooperação internacional.

Para a compreensão da abordagem de Martin, um ponto é essencial: a compreensão da lei de antecipação das preferências. Pressupondo que a partir do momento em que o Executivo reconheça que a instituição legislativa é um ponto de veto importante no processo, será compelido a considerar suas preferências, pois, caso contrário, poderá ter suas propostas vetadas. Conforme Cox e Morgenstern (2002, p. 447), isso implica que a atuação do Legislativo no processo político não requer uma posição pró-ativa; ela pode decorrer da habilidade da instituição de exercer seu poder de veto de forma eficiente. A conclu- 
são deriva da distinção entre "influência" e "participação" (activity). Segundo Martin (2000, p. 7),

Influência e participação não são idênticas, nem possuem necessariamente um alto grau de correlação. Os atores que detêm mais poderes, sendo aqueles que exercem mais influência sobre o resultado do processo, talvez sejam aqueles que precisem praticar menos ações. ${ }^{4}$

Nesse sentido, para se avaliar a influência de determinado ator político no processo decisório, o mais adequado é se ater mais aos resultados do que no processo em si.

Além do mais, no que diz respeito à política externa, a relação entre Executivo e Legislativo ocorre em um contexto de delegação, em que o Legislativo é o mandante (principal) e o Executivo o agente. A partir do momento em que se reconhecem os poderes do mandante, deve-se, necessariamente, discutir a lógica da delegação e as formas por meio das quais o principal é capaz de controlar o agente. Nesse sentido, Martin (2000) vai buscar subsídios para tentar entender a lógica da delegação no âmbito da política externa em uma literatura que se baseia, sobretudo, em estudos que dizem respeito ao controle legislativo sobre agências executivas.

De acordo com um dos expoentes dessa literatura: "A delegação ocorre quando uma pessoa ou grupo, o principal, seleciona uma outra pessoa ou grupo para agir a seu favor." (MCCUBBINS, 1999, p. 150). Os motivos para se delegar poderes são, geralmente, calcados na busca de eficiência. Quando o agente pode fazer a tarefa do principal de forma mais eficiente, existem incentivos para a delegação. Mas há uma série de problemas (delegation dilemma) que podem advir dessa relação, sendo o caso extremo a situação na qual a delegação se transforma em abdicação, dada a total perda de controle do principal sobre o agente. 
A delegação de poderes do Legislativo para o Executivo, no entanto, não implica necessariamente abdicação - como muitos afirmam -, pois, apesar da delegação, o Legislativo ainda pode deter meios para monitorar a atividade do agente. A delegação só irá se converter em abdicação quando esses meios não forem suficientemente eficientes para fazer prevalecer os interesses do principal (MCCUBBINS; SCHWARTZ, 1984; MCCUBBINS, 1999; MCCUBBINS; LUPIA, 2000).

Assim, a análise dos meios pelos quais o Congresso pode agir como um importante ponto de veto, e, portanto, manter um controle sobre a delegação de poderes em matéria de política externa, é de extrema importância. As formas de atuação são variadas. A Casa Legislativa pode atuar, primeiro, durante o processo de aprovação do acordo internacional, quando, geralmente, é facultado à instituição ratificar o documento - atuação ex post. Mas pode também interferir em fases secundárias, quando forem demandadas mudanças na legislação doméstica ou em destinação orçamentária específica (power of the pur$s e$ ) - fase de implementação. Uma segunda forma de atuação pode ser estabelecida por meio de mecanismos de monitoramento congressuais (congressional oversight), denominados pela literatura de police patrol e de fire alarms. ${ }^{5}$

No estudo, Martin (2000) apresenta proposições, que são transformadas em hipóteses e testadas em estudos de caso. Para os fins deste artigo, a atenção recai sobre a primeira, que diz respeito à influência do Legislativo sobre a política externa, informando que a delegação de poderes pode ser um mecanismo de influência. O passo inicial para a formulação está na compreensão de que, apesar de o Legislativo conceder à política externa a mesma preocupação que concede às demais políticas públicas, a forma de se lidar com ela é diferente, pois o Executivo está mais apto para tal atividade. A maneira pela qual o Legislativo pode influenciar o processo, de forma mais eficiente, é trabalhando com o Executivo, por meio da delegação de pode- 
res. Portanto, a delegação não pode ser entendida como uma abdicação. Com base nessa primeira proposição, objetiva-se entender a variação nos padrões de delegação, ou, mais especificamente, dos incentivos da delegação (MARTIN, 2000, p. 32). Espera-se que o Legislativo transfira mais poder ao Executivo quando aquele acreditar que o agente estará apto a defender suas preferências.

Martin formaliza a primeira proposição em duas hipóteses: a primeira é a hipótese da delegação, que busca explicar em que momento e por que razão o Legislativo irá reclamar maior participação na política externa, informando que, caso haja conflito de interesses entre os Poderes Executivo e Legislativo, os parlamentares buscarão institucionalizar a participação. A hipótese nula, neste caso, é a da abdicação, que informa que, ao delegar poderes, a instituição abre mão da possibilidade de influir no processo político em questão. A segunda é a hipótese da influência, que estipula que o Executivo não tem capacidade para interferir nos arranjos institucionais de modo a diminuir a influência do Legislativo, sendo a hipótese alternativa a da evasão.

As hipóteses formuladas por Martin (2000), portanto, servirão de base para o presente estudo. No entanto, como foram formuladas para uma realidade política distinta da latino-americana, ao final desta primeira parte, desenvolve-se um argumento para se tentar adaptá-las ao caso chileno.

\subsection{Legislativo no Chile}

O debate acadêmico acerca da relação entre o Executivo e o Legislativo na América Latina iniciou-se marcado pela visão crítica daqueles que percebiam uma primazia absoluta do primeiro sobre o segundo (LINZ, 1994; O’DONNELL, 1992; 1993; VALENZUELA, 1998), colocando em risco o próprio processo de redemocratização em curso na região. Uma segunda geração de estudos apresentou uma realidade mais complexa: uma variedade de presidencialismos 
Poder Legislativo e Política Externa: Um

Estudo sobre a Influência do Congresso...

(LANZARO, 2001; MAINWARING; SHUGART, 1993; 1997a; JONES, 1995; CAREY; SHUGART, 1992). Nos últimos anos, trabalhos mais recentes, já não tão marcados pela relação entre sistema de governo e sobrevivência democrática ou governabilidade, e dando mais atenção ao efetivo papel cumprido pelo Poder Legislativo nos países latino-americanos no processo decisório, trazem apontamentos semelhantes, no sentido de negar a homogeneidade para as análises sobre os Parlamentos latino-americanos, marcados pela alcunha de instituições marginais, quase sempre à sombra do Executivo, no qual o interesse provinciano e disputas políticas menores prevalecem (MORGENSTERN, 2002a; 2002b; COX; MORGENSTERN, 2002; SAIEGH, 2005; STEIN et al., 2006). Assim, ao lado da variedade de "presidencialismos", apontam uma "variedade de Legislativos", que tendem a ter comportamentos diferentes em razão da diversidade dos poderes constitucionais dos presidentes, dos sistemas partidários e da organização legislativa.

Voltando-se ao caso chileno, ao longo da história política do país, o Congresso Nacional foi considerado uma instituição central e a arena política mais relevante durante o século XX (COLLIER; SATER, 1998; HUNEEUS; BERRÍOS, 2003; NOLTE, 2003). Entre os anos de 1891 e 1924, na vigência do parlamentarismo, foi órgão decisório máximo, além de ter funcionado, ininterruptamente, por mais de 120 anos, um dado surpreendente para o contexto político latino-americano. Após o período autoritário, com a restauração da democracia por meio da transição negociada, mas com a manutenção da Constituição de 1980 e com a adesão a regras eleitorais impostas pelos militares (NAVIA; HEISS, 2003), a percepção sobre o Congresso modificou-se radicalmente. A principal razão foi o estabelecimento de um Poder Executivo forte, com uma série de prerrogativas constitucionais que lhe garantiam vantagens no processo legislativo e o qualificam como o clássico agenda-setter (CAREY; BALDEZ, 2001; ALEMÁN, 2003; TSEBELIS; ALEMÁN, 2005; ANINAT; 
LONDREGAN, 2006). Entre as prerrogativas constitucionais, estão poderes de iniciativa exclusiva da Presidência, decreto de urgência e poderes de veto, que seguem o padrão institucional estabelecido pelas principais democracias da região.

Diante desse cenário, grande parte da literatura anunciava a fragilidade e os perigos desses arranjos institucionais (VALENZUELA, 1998). Outros indicavam que o Chile seria o país com maior tendência de instabilidade de regime (CAREY; SHUGART, 1992, p. 150-166), pois, como se supunha que o presidente detinha poderes partidários muito fracos, com o passar dos anos, a tendência seria que o Executivo usasse com muito mais freqüência seus poderes constitucionais (MAINWARING; SHUGART, 1997b, p. 430). Argumentou-se, também, que, apesar de o Chile desfrutar da pior estrutura institucional da América Latina, a governabilidade alcançada durante os governos Patrício Aylwin (1989-1993) e Eduardo Frei Ruiz-Tagle (1994-2000) seria resultado do contexto da transição política, que gerou presidentes moderados (SIAVELIS, 2000). Em suma, com o hiperpresidencialismo, um Legislativo fraco, um sistema multipartidário e fragmentado, e a necessidade de quoruns altos para reformas constitucionais, não haveria incentivos para a cooperação entre os Poderes e para a formação de coalizões.

Contrapondo-se à literatura supracitada, e tendo a seu favor os reconhecidos índices de governabilidade do Chile nos últimos dezesseis anos (STEIN et al., 2006) e a relação cooperativa e eficiente entre os Poderes Executivo e Legislativo, Carlos Huneeus e Fabiola Berríos (2003, p. 62) afirmam que a autoridade do presidente é menor do que se argumenta à luz da Constituição e que o Congresso tem um papel mais relevante do que aparenta. Os autores apresentam críticas contundentes aos trabalhos de Carey e Shugart (1992), Mainwaring e Shugart (1997a) e Siavelis (2000) pelo excessivo peso dado aos aspectos formais e à falta de análise empírica. Apesar de o esforço ser menos uma abordagem sistemática do que uma crítica a esses estu- 
dos, chama-se a atenção para pontos relevantes da prática política chilena. Nessa mesma linha, outros estudos buscam diagnosticar as falhas em previsões pretéritas e apresentar explicações para a governabilidade chilena. Nolte (2003) destaca a capacidade do sistema político chileno de gerar coalizões estáveis e aponta um aumento crescente da participação de parlamentares junto ao Executivo, especialmente em razão da maior profissionalização e do alto índice de reeleição dos congressistas. Em recente trabalho, Siavelis (2005) também reconhece falhas de parte da literatura para explicar o caso chileno e se debruça sobre as instituições informais que prevalecem no dia-a-dia em detrimento das regras formais. ${ }^{6}$

De maneira geral, apesar do reconhecimento de o Executivo ser, indiscutivelmente, o ator político central no Chile, com amplos poderes para influir na agenda legislativa, é também pouco questionável o fato de o Congresso estar ganhando espaço e demonstrando possuir influência na agenda política nacional. A experiência democrática dos últimos dezesseis anos vai de encontro aos argumentos que apontavam o sistema político chileno como um sistema partidário fragmentado e multipartidário, concluindo que ele seria o modelo mais tendente à instabilidade - ou a pior estrutura institucional -, o que corroboraria para a fraqueza do Legislativo.

Literatura institucionalista mais recente explica a formação das duas coalizões - e a própria estabilidade do sistema - por meio dos incentivos gerados pelas regras eleitorais em vigência. Estudos sobre a organização legislativa indicam outras variáveis, como o alto índice de reeleição dos legisladores $(60 \%)^{7}$ e o nível de profissionalização que a instituição vem alcançando, se comparado com os padrões latino-americanos (CAREY, 2002; NOLTE, 2003; ANINAT et al., 2004; SAIEGH, 2005), para explicar a força política do Congresso. Acredita-se, pois, que apesar de o Executivo chileno ter muitas prerrogativas constitucionais, o Congresso é o mais eficiente e mais bem preparado da região (STEIN et al., 2006, p. 159). 
As análises recentes concernentes à interação entre o Executivo e o Legislativo, portanto, apresentam uma realidade muito mais complexa do que o retratado na primeira década, indicando uma crescente capacitação e participação do Poder Legislativo na vida política do país.

\subsection{Hipóteses}

Para se averiguar se o Legislativo chileno tem capacidade para influenciar o processo decisório da política externa, serão testadas duas hipóteses desenvolvidas por Martin (2000): a hipótese da delegação e a hipótese da influência. A primeira informa que o Poder Legislativo (principal) institucionalizaria a participação no processo decisório, buscando aumentar seu poder, supondo que exista conflito de interesses com o Poder Executivo (agente). A hipótese nula para esse caso seria a que Martin denomina de hipótese da abdicação, que indica que toda delegação representa abdicação, pois, em face de problemas com o agente, o principal seria incapaz de fazer valer seus poderes.

A segunda hipótese é a da influência, que informa que o Executivo seria incapaz de manipular as estruturas de participação do Legislativo para impedir que a instituição participe do processo decisório do qual delegou poderes. A hipótese nula, neste caso, seria a hipótese da evasão: o Poder Executivo teria capacidade de criar empecilhos à participação do Poder Legislativo quando este buscasse questionar a delegação.

É necessário, no entanto, fazer uma ressalva - e adaptação - em relação à hipótese da delegação antes de aplicá-la ao estudo de caso proposto. Ao elaborá-la, Martin (2000) tem em mente a delegação de competências do Poder Legislativo para o Poder Executivo em matérias que envolvam negociações internacionais tendo como paradigma, no caso de regimes presidencialistas, o modelo norte-americano, no qual a Constituição declara que a competência para regular o comércio pertence ao Poder Legislativo. ${ }^{8}$ 
No caso do Chile - e pode ser estendido aos países sul-americanos -, no entanto, em matéria de política comercial, a lógica da delegação do Legislativo para o Executivo não pode ser aplicada, uma vez que este já concentra, originalmente, demasiado poder no processo decisório em questão. A Constituição da República delimita as competências dos dois Poderes de forma muito clara, no que diz respeito tanto à competência para negociar acordos comercias como à competência para alteração de tarifas, deixando ainda mais evidente a assimetria entre os Poderes. Segundo as normas constitucionais, a tarefa de negociar acordos comerciais é do Poder Executivo, cabendo ao Poder Legislativo ratificá-los; e, sobre competência de alterar tarifas, apesar de informar que a medida só pode ser tomada por meio de lei ordinária, a lei, neste caso, deverá ser de iniciativa exclusiva do presidente da República.

No que diz respeito à competência sobre política comercial, a balança pende para o Executivo. Ao logo da última década, porém, o Legislativo vem buscando aumentar seu âmbito de influência sobre diversas políticas públicas - a literatura indicada anteriormente aponta para essa direção. Em matéria orçamentária, por exemplo, uma área na qual a Constituição de 1980 concedeu maior competência ao Executivo, estudos recentes apontam que, durante a década de 1990, o Congresso aumentou sua capacidade de ação junto ao Executivo sobre o tema (MONTECINOS, 2003). Isso ilustra, pois, o progressivo aumento de influência dos parlamentares em assuntos que eram, originalmente, de competência do Executivo, tal como disposto na Constituição de 1980. Assim, o fato de se detectar que não há delegação não impede que se busque adaptar a hipótese da delegação de Martin (2000) para o caso chileno.

Nesse sentido, com base na idéia de que o Poder Legislativo institucionaliza sua participação no processo decisório, buscando aumentar seu poder, uma vez que exista conflito de interesses com o Poder Executivo, para os fins específicos deste trabalho, desenvolve-se a 
hipótese do aumento de poder do Legislativo. Tal hipótese informa que, em temas de política externa, que originalmente são de competência do Poder Executivo, o Legislativo vai procurar aumentar seu poder no processo decisório em razão de buscar o atendimento de suas preferências quando houver a emergência de visões conflitivas. Ou seja, a não-manifestação do Congresso não poderá ser tomada como uma atitude de submissão ou resignação diante do Executivo, pois sinaliza concordância. A hipótese nula, neste caso, seria a hipótese da resignação.

\section{Competências do Poder Executivo e do Poder Legislativo}

Decorre da interpretação do art. 32, n⿳⼈ 15, da Constituição chilena que o Poder Executivo é o responsável pela condução da política externa, o que inclui a política comercial. Assim, conforme o dispositivo constitucional sobre negociações e tratados internacionais, é da competência do presidente da República conduzir as relações com outros países, sendo responsável pelas negociações internacionais. No que diz respeito a outro instrumento importante da política comercial, a competência para alterar tarifas - imposto de importação -, a Constituição informa que é uma iniciativa exclusiva da Presidência da República, vide o art. 65, nº 1, cabendo tão-somente ao chefe do Executivo apresentar projeto de lei sobre a matéria.

No que diz respeito ao poderes do Congresso, historicamente, seus mecanismos institucionais para participar do processo decisório são considerados limitados. Excetuando-se o período conturbando do início do século XIX, entre os anos de 1811 e 1828, durante o processo de independência, quando, por meio do Reglamento para el Arreglo de La Autoridade Ejecutiva, de 1811, chegou-se a conferir ao Parlamento a competência para conduzir a política externa do país, a 
Poder Legislativo e Política Externa: Um Estudo sobre a Influência do Congresso...

regra que prevaleceu na Constituição de 1833, na de 1925 e na atual, de 1980, foi a da dominância do Executivo, com escassas fontes de poder ao Legislativo (MEDINA, 2003).

Mesmo após a redemocratização, as regras estabelecidas pela Constituição de 1980 pouco se alteraram no que diz respeito à divisão de competências entre o Executivo e o Legislativo em matéria de política comercial. Um dos poucos dispositivos modificados foi o art. 50, $\mathrm{n}^{\mathrm{o}}$ 1, que tratava da participação do Congresso no processo de retificação de tratados internacionais; no entanto, não houve alterações substantivas. Este artigo veio dar mais clareza ao texto original, que, em razão das ambigüidades, gerou polêmicas no Congresso, especialmente em matéria de tratados internacionais sobre comércio. ${ }^{9}$

O essencial do art. 50, $\mathrm{n}^{\mathrm{o}} 1$ - agora art. 54 -, foi mantido: cabe ao Poder Legislativo aprovar ou vetar acordo internacional negociado pelo presidente. Os tratados internacionais obedecem ao mesmo trâmite dos projetos de lei; entretanto, um aspecto deve ser sublinhado: acordos internacionais que visem a implementação de tratados já assinados não precisam de ratificação do Congresso. Assim, se um acordo internacional for decorrência de um acordo anterior (tratado-marco), ou seja, tiver como objetivo aprofundá-lo ou regulá-lo, e tiver sido celebrado pelas mesmas partes e não abordar matérias de lei, ele pode entrar em vigor por meio de decreto, sem consentimento do Congresso Nacional. ${ }^{10}$

Quanto à política tarifária, os poderes institucionais do Congresso para influir na decisão de redução ou aumento de tarifa de importação podem ser considerados mais abrangentes. As Constituições de 1833 e de 1925 determinavam que, para qualquer alteração, seria necessária lei ordinária, com origem na Câmara dos Deputados. Ou seja, a matéria não estava à mercê do poder discricionário do Executivo. No que diz respeito à alteração tarifária e à Constituição de 1980, a norma constitucional repete as Constituições de 1833 e 1925, 
e informa que a matéria só pode ser tratada mediante lei ordinária. Deve-se recordar, no entanto, que o art. $65, \mathrm{n}^{\mathrm{o}} 1$, aponta que a medida é de iniciativa exclusiva do presidente da República.

Pode-se concluir, portanto, sem muita dificuldade, que a balança pende, indiscutivelmente, para o lado do Executivo. Ele conduz as negociações e detém prerrogativas legais para introduzir matéria sobre política tarifária, além de possuir um corpo institucional especializado e altamente capacitado ao seu dispor, o que faz com que determine a agenda e controle as informações. O Legislativo, por outro lado, é um importante ponto de veto, cabendo a ele ratificar acordos internacionais e propostas de redução ou aumento de tarifas. Sua ação é limitada à atuação ex post. No entanto, conforme anunciado anteriormente, esse fato não marginaliza a instituição no processo decisório, podendo permitir que parlamentares influenciem no resultado das políticas públicas.

\section{O Poder Legislativo e a Política Comercial}

Nesta última parte, a hipótese do aumento de poder do Legislativo e a hipótese da influência são testadas diante da análise da participação do Congresso Nacional nos processos de negociação dos Acordos de Complementação Econômica (ACEs) que o Chile assinou na década de 1990 e das duas votações de redução de tarifas, ocorridas em 1991 e em 1998. Buscou-se confrontar processos políticos semelhantes, nos quais ora o Congresso procurava se manifestar, ora se abstinha. No primeiro caso (isto é, quando o Congresso procurava se manifestar) são contrapostos os casos dos ACEs que o Chile negociou com Argentina, México, Bolívia, Venezuela, Colômbia e Equador com a aprovação do ACE-35, que permitiu a associação do Chile ao Mercosul, e do ACE-38, com o Peru. No segundo caso, são cotejados os processos de negociação de dois programas de abertura unilateral na década de 1990: o primeiro, ocorrido em 1991, quando, por meio da 
Lei $\mathrm{n}^{\mathrm{o}} 19.065$, reduziu-se as tarifas sobre importação de $15 \%$ para $11 \%$; e o segundo, em 1998, com a promulgação da Lei n⿳⺈ 19.589 , que estabeleceu uma redução tarifária gradual, de um ponto percentual por ano, com o objetivo de atingir a meta de 6\% em 2003.

\subsection{Congresso Nacional e os ACEs negociados na década de 1990}

Durante os anos 1990, quando o Chile deu início à política comercial bilateral, os primeiros acordos foram fechados com países latino-americanos, e um dos principais instrumentos à disposição da Chancelaria foram os Acordos de Alcance Parcial (AAPs) de Complementação Econômica, mais conhecidos como Acordos de Complementação Econômica (ACEs). ${ }^{11}$ Dado o seu caráter simplificado, especialmente em face dos Tratados de Livre Comércio (TLCs), que hoje em dia vão muito além da redução tarifária, os ACEs também são implementados de forma bastante simples. No caso específico do Chile, prevaleceu, tradicionalmente, o argumento de que os ACEs se consubstanciam em implementações do Tratado de Assunção de 1980 (TA-80); logo, não necessitavam do processo de ratificação por parte do Congresso Nacional para sua validação, uma vez que o acordo-marco, o TA-80, já estava em vigência no país. Eram simplesmente incorporados ao ordenamento jurídico por meio de decreto emitido pelo chefe do Executivo. A interpretação decorria de dispositivos constitucionais. Portanto, esse foi o procedimento adotado para a internalização dos compromissos comerciais negociados pelo Chile, sob a forma de ACE, durante os primeiros anos da década de 1990.

O primeiro acordo comercial bilateral negociado pelo Chile foi o ACE-16, em 1991, com a Argentina, que tratou de acordos de dupla tributação, de proteção de investimentos e questões relacionadas à integração física. No mesmo ano, negociou o ACE-17 com o Méxi- 
co. A aproximação com este país foi motivada por razões econômicas e políticas. Ambos haviam alcançado um nível de abertura comercial semelhante, em decorrência das reformas liberais postas em prática anos antes, um fato que colaborava para a aproximação. Nos anos seguintes, o governo concentrou-se nas negociações comerciais com os países que integravam a Comunidade Andina de Nações (CAN), bloco do qual deixou de fazer parte em 1976. Em 1992, iniciaram-se as negociações do ACE-22 com a Bolívia, do ACE-23 com a Venezuela e do ACE-24 com a Colômbia, que foram concretizadas em 1993. Em 1994, negociou-se o ACE-32 com o Equador e iniciaram-se as primeiras conversações com o Peru.

Nas negociações dos ACE-16, ACE-17, ACE-22, ACE-23, ACE-24 e ACE-32, o aspecto que se pretende destacar é que nenhum deles passou pelo trâmite ordinário ao qual os tratados internacionais deveriam obedecer, qual seja, após a sua conclusão, ser encaminhado para a ratificação do Congresso Nacional. Todos foram introduzidos no ordenamento jurídico nacional por meio de decretos do Executivo. ${ }^{12}$ É importante ressaltar que não se encontra registro que possa apontar tentativa do Congresso Nacional em intervir no processo, requisitando aprovação ex post.

No caso do acordo entre o Mercocul e o Chile, mesmo se tratando de um ACE, o processo de aprovação foi mais complexo, conforme se constatará a seguir. Em junho de 1994, durante o governo Eduardo Frei, o Chile decidiu oficializar suas intenções para se associar ao Mercosul. As negociações aceleraram-se durante o ano de 1995 e, em março de 1996, o governo, por meio do então ministro das Relações Exteriores, José Miguel Insulza, declarou que já estava encerrado e que o acordo seria assinado em junho de 1996, com previsão de entrar em vigor no dia $1^{\underline{o}}$ de julho de $1996 .^{13}$

O acordo de associação entre o Chile e o Mercosul foi negociado sob a forma de um ACE (ACE-35). Previa-se, logo, que fosse introduzi- 
do no ordenamento jurídico doméstico por meio de decreto, sem a necessidade de ratificação por parte do Congresso, conforme ocorreu com os outros seis acordos desta natureza que o país havia subscrito nos anos anteriores. No entanto, dada a amplitude do ACE-35 e a diversidade de interesses que estavam em jogo-, houve divergências no Congresso e a necessidade de esclarecimentos, o que tornou inviável o planejamento inicial do Executivo de evitar que o acordo fosse levado ao Parlamento.

Em março de 1996, ao comunicar ao Congresso o fim das negociações do ACE-35, o governo foi enfático ao se posicionar a respeito do procedimento de ratificação. Isso se deu por meio de seus principais porta-vozes, à época, e, sobre o tema, no Congresso: o ministro das Relações Exteriores, José Miguel Insulza, o ministro da Economia, Álvaro Garcia, e o ministro do Interior, Carlos Figueroa. Em declarações à imprensa e nas duas visitas que os ministros fizeram ao Congresso - tanto à Câmara quanto ao Senado -, insistiram que não havia necessidade de o acordo ser ratificado pelo Legislativo. Os principais argumentos baseavam-se no fato de que a instituição já estava informada o suficiente a respeito dos termos do acordo, uma vez que membros do Ministério das Relações Exteriores (MRE), do Ministério da Agricultura e do Ministério da Economia eram freqüentemente convocados para comunicar o andamento das negociações, e que as duas Casas Legislativas teriam acesso ao acordo um mês e meio antes da assinatura (SENADO..., 1996). Também se insistiu bastante no aspecto jurídico-formal, ao se reafirmar o caráter instrumental dos ACEs na tradição chilena de implementá-los via decreto. O Executivo argumentava que houve uma delegação de poderes legislativos, concretizada com a implementação do TA-80 (TRATADOS..., 1996).

O governo tinha vários motivos para tentar evitar que o acordo fosse levado a plenário, pois, apesar de deter maioria na Câmara, não a tinha no Senado. ${ }^{14}$ Ademais, a matéria era tema de discórdia tanto 
dentro da coalizão governista como entre os parlamentares da oposição. Dentre os principais motivos, destacava-se a questão da proteção ao setor agrícola tradicional, que mobilizava boa parte dos parlamentares. Estavam, assim, do mesmo lado grande parte dos membros da União Democrática Independente (UDI) e da Renovação Nacional (RN) e setores do Partido Democrata Cristão (PDC) e do Partido Socialista (PS). A esse contexto, somava-se o lobby que a Sociedade Nacional Agrícola (SNA) buscava pôr em prática, e que preocupava o governo.

Não havia, no entanto, uma proposta consolidada daqueles que poderiam se opor ao acordo. Desde o anúncio de março, a SNA argumentava que não teve seus interesses atendidos, ${ }^{15}$ e por isso se opunha, frontalmente, ao acordo Chile-Mercosul. Políticos da oposição, por outro lado, exigiam compensações às possíveis perdas do setor (NO HAY..., 1996). Ao mesmo tempo, o tema de um segundo programa de abertura unilateral começava a se associar ao debate.

No momento em que o governo fez o anúncio de que as negociações chegavam ao fim, faltando, tão-somente, questões pontuais para serem definidas, e deixou clara sua vontade de evitar que o acordo passasse, formalmente, pelo escrutínio parlamentar, a reação dos congressistas foi imediata. A postura da oposição, por razões óbvias, foi mais contundente, mas governistas demonstravam certo desconforto com a inflexibilidade do Executivo, como os deputados José Antonio Viera Gallo (PS) e Francisco Huenchumilla (PDC), que declararam haver dúvidas razoáveis a respeito da situação (CONGRESO..., 1996; PARLAMENTARIOS..., 1996). O Senado, em que o governo não contava com a maioria, procurou mobilizar-se e pressionar o Executivo para que o acordo fosse enviado ao Legislativo o quanto antes. Ao final de março, a Comissão de Constituição, Legislação e Justiça iniciou processo de análise da proposta governista.

Algumas semanas depois, em 16 de abril de 1996, o Senado aprovou, por dezoito votos a favor e seis abstenções, projeto de acordo que de- 
finia sua posição diante da questão, posicionando-se, como esperado, a favor da tramitação legislativa (REPÚBLICA DE CHILE, 1996a). Parte dos argumentos da oposição concentrava-se em aspectos técnicos, e reafirmava-se que o ACE-35 não dispunha das prerrogativas do art. 50 da Constituição, que permitia que determinados acordos fossem internalizados sem o processo de ratificação legislativa. ${ }^{16}$ Ao mesmo tempo, outros argumentavam que, independente da forma que fosse adotada, o ACE-35 representava um marco político para o país, e deveria ser analisado pela instância Legislativa, o que seria uma maneira de conceder mais legitimidade ao processo.

Diante da pressão política, o governo Frei decidiu, por fim, voltar atrás e enviar a matéria ao Congresso Nacional, para que o ACE-35 fosse examinado pelos parlamentares. $\mathrm{O}$ anúncio foi feito pelo chanceler Insulza, que explicou o gesto como sendo um ato político de benevolência do presidente Eduardo Frei, em vez do cumprimento de um dever legal ou reflexo de pressões políticas, e que a ação não implicaria a perda das prerrogativas de que o Executivo goza sobre a matéria (CONSENSO..., 1996; EL CONGRESO..., 1996). Apesar de os parlamentares terem elogiado a decisão do presidente, a interpretação do ato, no entanto, foi bem diferente do que a apresentada pelo chanceler. A grande maioria entendeu que o governo se antecipou a um resultado que seria inevitável.

Uma vez acertado o trâmite do ACE-35, as discussões subseqüentes ficaram restritas ao tipo de procedimento que prevaleceria no Legislativo, à barganha política em torno das votações e das exigências que poderiam ser atendidas pelo governo. O procedimento acordado entre o governo e os parlamentares foi o de um tratado internacional ordinário. Desta forma, não se poderia apresentar emendas, nem aprová-lo com restrições. No que diz respeito às negociações políticas, tudo girava em torno da proteção ao setor considerado o mais prejudicado com o acordo: o agrícola tradicional. 
No início do processo legislativo, não houve resistência para se aprovar na Câmara o projeto de acordo: em 18 de julho, ele foi aprovado pela Comissão Especial do Mercosul da Câmara dos Deputados por nove votos a favor, três contra e uma abstenção; no mês seguinte, passou, sem maiores problemas, pelo plenário da Casa Legislativa. O resultado foi 76 votos a favor, incluindo todos os membros da coalizão Concertación e alguns representantes da UDI e da RN; 26 contra; e três abstenções. Diante desse cenário, o governo manteve postura inflexível, indicando que não cederia mais às pressões do setor agrícola. ${ }^{17}$ Ao final de agosto, declarou, por meio do ministro da Agricultura, que era inviável implementar os pedidos feitos pela SNA no mês de julho, entre eles, subsidiar a compra de fertilizantes e reduzir a zero as tarifas de importação sobre insumos e bens de capital para o setor.

A postura do governo começou a mudar, no entanto, quando a matéria foi levada ao Senado. O primeiro sinal dado pela instituição sobre as dificuldades que o Executivo iria enfrentar diante da oposição - e, até mesmo, diante de parlamentares da base aliada - foi o rechaço ao nome de Carlos Massad para o cargo de conselheiro do Banco Central, horas antes das Comissões Unidas de Agricultura, Finanças e Relações Exteriores do Senado começarem a discutir o ACE-35. Todavia, mais uma vez antecipando-se às dificuldades da aprovação do acordo de associação ao Mercosul, representantes do governo iniciaram negociações diretas com líderes da oposição, com o fim de dirimir as divergências em torno do acordo. A negociação final foi conduzida pelo chefe da Secretaria Geral da Presidência (Segpres), Genaro Arriagada, pelo ministro da Fazenda, Eduardo Aninat, pelo ministro da Economia, Alvaro Garcia, e pelos senadores Sebastián Piñera (RN) e Sergio Diez (RN) (ALTA...,1996; GOBIERNO SE COMPROMETIO..., 1996; APROBADA..., 1996; LOS VAIVENES..., 1996; PACTO..., 1996). 
As propostas apresentadas pelos parlamentares congregavam tanto os interesses daqueles advindos de regiões onde prevalecia a agricultura tradicional como as antigas demandas daqueles mais afeitos ao livre-comércio, e convergiam com as preferências de setores exportadores, que exigiam a diminuição de custo. Em suma, podem ser assim resumidas: em termos substantivos, as duas exigências centrais diziam respeito à queda do imposto de importação e de um programa de assistência à agricultura tradicional. Exigiam-se a implementação de um novo programa de abertura unilateral, seguindo os moldes do que fora posto em prática em 1991, para ser discutido já no ano seguinte, e um compromisso explícito para com o setor agrícola tradicional, calcado em compensações financeiras. Além do mais, foi pedido empenho do governo para que convencesse os demais membros do bloco a apoiarem a criação de um mecanismo de solução de controvérsias e para que fosse incorporada ao acordo, no futuro, matéria relativa a serviços. Tendo em vista não só o interesse do governo em concretizar, o mais rápido possível, o acordo com o Mercosul, mas também o fato de que as demandas parlamentares não colocavam em perigo o projeto de associação com o Mercosul e muito menos a estratégia do regionalismo aberto, o Executivo viu-se obrigado a aceitar as propostas do Legislativo.

Em 9 de setembro de 1996, na véspera da votação e diante do plenário do Senado, o ministro Aninat tornou público o compromisso do governo de implementar um segundo programa de abertura unilateral. Não foram informados detalhes do plano, nem uma agenda definida. Na ocasião, o que se adiantou foi que a abertura representaria uma queda de quatro a seis pontos sobre a tarifa de importação e que seria estabelecida de forma gradual. A única garantia que o governo poderia dar - e deu - era declarar o compromisso publicamente, como o fez Aninat (REPÚBLICA DE CHILE, 1996b).

Ao mesmo tempo que Aninat informava a respeito do compromisso com a segunda abertura unilateral, o ministro da Agricultura, Emilia- 
no Ortega, anunciava o novo plano compensatório do governo para o setor agrícola tradicional em um café-da-manhã com líderes partidários no dia em que seria realizada a votação. A proposta governista foi ao encontro das demandas dos congressistas. O Estado assumiria o compromisso de destinar US $\$ 500$ milhões ao setor agrícola em um período de cinco anos, quantia que, à época, representava $0,6 \%$ do produto interno bruto (PIB). Nos quatro primeiros anos, seriam liberados US\$ 350 milhões; e o restante, US\$ 150 milhões, em 2001. Foi também anunciada a eliminação de tarifas sobre a importação de $85 \%$ dos insumos agrícolas e confirmadas as linhas de crédito da Corporación de Fomento de la Producción (Corfo) e do Banco del Estado, uma das demandas da SNA (PRESUPUESTO..., 1996).

Apesar de parte dos parlamentares ter demonstrado insatisfação pelo fato de não haver informações suficientes sobre a implementação das medidas, tanto sobre o programa de abertura unilateral quanto a respeito do pacote de ajuda ao setor agrícola, o resultado dos anúncios de comprometimento do governo com as propostas defendidas pelos parlamentares teve o efeito desejado. Assim, o acordo de associação do Chile ao Mercosul (o ACE-35) foi aprovado sem maiores problemas no Senado. A votação ocorreu no dia 10 de setembro de 1996, tendo 36 votos a favor, três contra e uma abstenção.

Outro caso no qual o Congresso buscou interferir foi no ACE-38, entre o Chile e o Peru. O acordo foi resultado de um processo de negociação longo e complexo, que refletiu a instabilidade da relação bilateral, marcada por décadas de disputas. Em 1998, o Peru era o único país da América do Sul que não havia fechado um acordo comercial com o Chile. Apesar de, a curto prazo, ter sido considerado comercialmente modesto, ele teve uma importância política fundamental para a galvanização da relação Chile-Peru e propiciou alterações no processo decisório da política comercial, no que diz respeito à participação do Legislativo. 
As consultas formais entre os dois países iniciaram-se ainda em 1994, tendo sido finalizadas somente quatro anos mais tarde, em junho de 1998. O ACE-38 foi assinado em 22 de junho de 1998, com previsão para entrar em vigor em $1^{\mathrm{O}}$ de julho. ${ }^{18}$ À época do anúncio oficial do fim das negociações, alguns deputados se manifestaram, trazendo à tona antigas exigências parlamentares, calcados em argumentos que foram utilizados durante a negociação do ACE-35, entre o Chile e o Mercosul. Os deputados governistas do PDC, Antonella Sciaraffia e Tomás Jocelyn-Holt, pediam uma discussão prévia no Congresso Nacional antes que o documento entrasse em vigor, pois, segundo eles, o ACE-38 afetava uma série de leis - Ley de Arica; Ley de lãs Zonas Francas; Ley del Reintegro Simplificado -, de modo que deveria estar sujeito à ratificação parlamentar. Membros do governo e da oposição mostraram-se contrários às exigências de Sciaraffia e Jocelyn-Holt, ${ }^{19}$ o que não impediu que se levasse o assunto à Controladoria Geral da República (CGR), resultando em mais de vinte dias de atraso para a entrada em vigor do acordo. Após a CGR ter negado o pedido dos parlamentares, o deputado Jocelyn Holt levou a matéria ao Tribunal Constitucional (TC), levando preocupação ao setor privado e ao Executivo.

Apesar da mobilização para postergar a entrada em vigor do ACE-38, o Senado e a Câmara dos Deputados cumpriram um importante papel para resolver o impasse. No início de julho, quando a matéria ainda estava sendo apreciada pela CGR, a Comissão de Relações Exteriores do Senado, após longo debate, emitiu comunicado informando que não seria necessária a tramitação do ACE-38 no Congresso Nacional (ACUERDO..., 1998). Em agosto, quando a matéria caminhava para o TC, a Câmara dos Deputados aprovou resolução que ratificava o acordo comercial com o país vizinho. A sessão foi secreta e resultou em 46 votos a favor e trinta contra (GOBIERNO ASEGURA..., 1998). Mesmo não participando formalmente do processo, o que exigiria o trâmite do acordo comercial 
pelo Congresso Nacional para a ratificação legislativa, a atuação da Câmara e do Senado pode ser considerada decisiva para auxiliar o MRE na tarefa de implementar, com celeridade, o ACE-38, garantindo, especialmente, o apoio político.

Para a entrada em vigor do ACE-38, no entanto, ainda foi necessária uma negociação direta entre um grupo de parlamentares - do governo e da oposição $-{ }^{20}$ e o chanceler Insulza, o que resultou na retirada, definitiva, do pedido feito pelos congressistas no TC (DIPUTADOS..., 1998). O acordo firmado entre os legisladores e o MRE deu origem à reforma do antigo art. $50, \mathrm{n}^{\mathrm{0}} 1$, que tratava do procedimento de ratificação de tratados internacionais aprovado em 2005. Além do mais, antes que o projeto se transformasse em lei, garantiu-se a concordância do Executivo de que qualquer matéria que envolvesse novo acordo comercial, inclusive ACE sob o marco da Associação Latino-americana de Integração (Aladi), seria enviada para a apreciação do Parlamento (GOBIERNO DEFINIÓ..., 1998; PORRAS, 2003).

\subsection{O Congresso Nacional e a implementação da abertura unilateral na década de 1990 - as Leis no 19.065/91 e 19.589/98 e as negociações entre 0 Executivo e 0 Congresso Nacional}

Nos anos 1990, a atenção dada aos acordos bilaterais não tirou da agenda política o objetivo de se trabalhar com uma economia aberta, com o mínimo de barreiras tarifárias, para aumentar a eficiência econômica. A implementação da primeira redução tarifária ${ }^{21}$ com vistas à abertura comercial unilateral deu-se por meio da aprovação da Lei n⿳0 19.065. Foi um processo político relativamente simples, pois havia consenso a respeito da necessidade da aprovação da medida entre 
membros do Executivo e do Parlamento. Em parte, o que explica o acordo entre os atores políticos domésticos foi o contexto da transição democrática. Após dezessete anos sob um regime autoritário de direita, uma coalizão de centro-esquerda chegou ao poder. Entre os tantos desafios com os quais se deparou, um deles foi o de manter a bem-sucedida política econômica liberal implementada pelo regime militar. A decisão de pôr em prática um programa de abertura unilateral por meio da redução tarifária, um dos principais instrumentos da política comercial do período Pinochet, foi um claro sinal aos mercados e ao mundo de que o governo recém-empossado buscaria conciliar os valores liberais herdados nos anos 1980 com a nova agenda política da Concertación.

O projeto de lei foi apresentado formalmente ao Congresso Nacional no dia 18 de junho de 1991. Sua tramitação iniciou-se na Câmara dos Deputados; em seguida, foi repassado ao Senado, onde sofreu modificações, e encaminhado para análise da Comissão Mista. O processo durou quatro dias, tendo sido repassado para a sanção presidencial no dia 21 de junho. ${ }^{22}$ A alteração mais substantiva do documento legislativo foi a redução tarifária uniforme de $15 \%$ para $11 \%$.

Diferente do processo de aprovação da Lei n⿳ํㅡㄹ 19.065 de 1991, marcado pela celeridade na tramitação e pelo consenso político, a negociação da Lei n ${ }^{0}$ 19.589, responsável pela segunda abertura unilateral nos anos 1990, foi mais complexa, marcada por divergências dentro da base governista e dentro da própria oposição, fato que obrigou o Executivo a fazer uma série de adaptações e concessões ao projeto original, na tentativa de vê-lo aprovado.

A origem da Lei $\mathrm{n}^{\mathrm{o}}$ 19.589 remonta às negociações entre o Executivo e o Legislativo para a aprovação do projeto de acordo do ACE-35, que permitiu a associação do Chile ao Mercosul. Mais especificamente, foi uma das condições estabelecidas pelos parlamentares para que o acordo fosse aprovado. Entre os argumentos daqueles que de- 
fendiam a proposta, estava presente a necessidade de se evitar um desvio de comércio e de ratificar o compromisso do país com o livre-comércio. Em 1996, o governo Frei havia se comprometido com parlamentares a implementar a medida no ano seguinte; no entanto, a matéria só ganhou força e começou a ser discutida, seriamente, no primeiro semestre de 1998. O principal interlocutor do governo no Congresso Nacional e no setor privado foi o Ministério da Fazenda, que, à época, era comandado pelo ministro Eduardo Aninat. Contudo, as participações dos Ministérios da Agricultura, da Economia e do Interior e da Segpres não podem ser desconsideradas.

Em março de 1998, o governo sinalizou que já tinha o projeto praticamente definido e que pretendia apresentá-lo ao Congresso Nacional ainda naquele mês, pois se tratava de uma questão prioritária. Em declarações à imprensa, Aninat afirmou que ainda faltavam detalhes técnicos a serem definidos, mas que os aspectos centrais já estavam acertados, entre eles (FREI..., 1998; PROYECTO..., 1998; "REBAJA DE ARANCELES SERÁ...", 1998; ARANCELES: OPOSICIÓN..., 1998):

- O percentual de desgravação seria de três pontos, o que levaria a tarifa de $11 \%$ para $8 \%$.

- A alteração seria aplicada de imediato, no ano de 1999.

- A aplicação seria uniforme; ou seja, não haveria discriminação para produtos sensíveis.

- Não haveria compensações financeiras a setores sensíveis.

- Haveria necessidade de compensar as perdas na arrecadação, calculadas em US\$ 420 milhões; portanto, a medida viria acompanhada de uma "minirreforma" tributária.

A reação dos parlamentares não foi uniforme. Setores da oposição, como a RN, receberam a notícia com satisfação e, apesar de discordarem da necessidade de compensações para a queda na arrecadação, acreditavam que este tópico poderia ser negociado. Por outro 
lado, parte da bancada governista foi taxativa ao afirmar que o assunto não seria prioridade caso o governo não se mostrasse flexível em determinados pontos da proposta. As demandas dos parlamentares governistas giravam em torno da gradualidade da aplicação da medida, da discriminação para produtos sensíveis e de medidas compensatórias para setores menos competitivos, como a agricultura tradicional e as pequenas e médias empresas (PMEs).

No setor privado, no entanto, a proposta foi bem recebida. A Confederação da Produção e do Comércio (CPC), a Sociedad de Fomento Fabril (Sofofa) e a SNA mostraram-se favoráveis ao projeto defendido pelo Ministério da Fazenda, tendo divergências pontuais: a CPC e a Sofofa propuseram queda de até cinco pontos percentuais, podendo ser a queda gradual; já a SNA, exigiu que, independente do percentual, ela fosse gradual. A Associação dos Exportadores de Manufaturas (Asexma), no entanto, foi bastante crítica ao projeto, demandando um tratamento diferenciado para as PMEs.

Diante do cenário apresentado, o maior problema estava dentro da própria Concertación, e, em vista do impasse, o Executivo optou por postergar o envio da matéria ao Congresso até que se alcançasse um acordo.

No dia 21 de maio, em mensagem presidencial ao Congresso Pleno na abertura da $338^{\underline{a}}$ legislatura, o presidente Eduardo Frei declarou que o projeto de redução tarifária era uma das prioridades na agenda legislativa do governo. Naquela oportunidade, apresentou as modificações ao esboço inicial que fora elaborado, no início do ano, por Aninat. Basicamente, o que se alterava era o percentual da reduçãode três para cinco pontos - e a forma de implementação, que seguiria uma gradualidade de três pontos já em 1999, um em 2000 e um em 2001. Além do mais, o presidente ressaltou que as perdas de arrecadação deveriam ser compensadas (FREI RUIZ-TAGLE, 1998). Nas semanas seguintes, apesar de todo o empenho que Executivo buscou 
demonstrar para aprovar a medida, a resistência legislativa continuou a dificultar o avanço das negociações.

No mês de junho, quatro senadores de regiões agrícolas tradicionais - Gabriel Valdés (PDC), Jaime Gazmuri (PS), Hernán Larraín (UDI) e Marco Cariola (sem partido) - emitiram comunicado criticando a proposta do Executivo e condicionando seus votos ao estabelecimento de um sistema de discriminação para produtos sensíveis. Os senadores exigiam que se mantivesse a lógica que prevaleceu nos acordos comercias assinados com o Mercosul e com o Canadá, quando se abriu a economia, mas se manteve uma proteção diferenciada para produtos considerados sensíveis, como trigo, beterraba, arroz, produtos lácteos, carnes, entre outros. De acordo com o comunicado, os senadores informaram que o Chile não deveria desgravar produtos que receberam tratamento diferenciado nesses acordos comerciais, porque, no período das negociações, teve que aceitar uma série de condições para poder garantir as exceções (SENADORES..., 1998).

No decorrer do mês, foram constantes as reuniões dos ministros Aninat, Carlos Figueroa (ministro do Interior) e Juan Villarzú (Segpres) com parlamentares do PDC. Uma das principais demandas do grupo era a proposta defendida pelo então presidente da Comissão de Finanças do Senado, Alejandro Foxley (PDC), que reclamava uma queda gradual da tarifa aduaneira de um ponto percentual por ano. Em julho, em reunião entre Aninat, Foxley e o presidente da Comissão de Finanças da Câmara dos Deputados, Andrés Palma (PDC), os parlamentares mostraram insatisfação a respeito da gradualidade da queda, mais especificamente com a fórmula $3+1+1$ que o governo defendia - isto é, no primeiro ano, redução de 3\%, seguida de queda de $1 \%$ nos dois anos seguintes.

Ao final do mês de julho, período no qual o Executivo pretendia enviar o projeto ao Congresso para votação, a repetida resistência parlamentar fez com que a decisão fosse postergada. Na ocasião, um 
grupo de dezessete senadores, ${ }^{23}$ de diversas bancadas, somou-se ao pedido feito no mês anterior por Valdés, Gazmuri, Larraín e Cariola, e emitiu nova nota com o seguinte pedido ao governo: "manter inalterada (com a taxa de 11\%) a situação de determinados produtos, como trigo, açúcar, carne, leite e oleaginosas" (ARANCELES: 17..., 1998). Segundo Cariola, que falou em nome do grupo:

Apoiamos a queda tarifária proposta pelo governo para todas as áreas da produção nacional. Estamos tão-somente pleiteando que essa queda respeite a gradualidade já estabelecida para os produtos sensíveis negociados com os países do Mercosul e com o Canadá (ARANCELES: 17..., 1998).

Outros parlamentares foram mais contundentes, como o senador socialista Gazmuri, que declarou que "se não houver exceção no programa de redução tarifária, não estou disposto a votar a favor do projeto no Congresso [...] mas espero que não tenhamos que chegar a esse extremo" (SE POSTERGA..., 1998).

Durante o mês de agosto, o Executivo começou a dar sinais de que poderia aceitar a proposta de maior gradualidade - um ponto por ano. Conforme declarou Aninat, após reunião com Foxley e Palma, "o governo estaria flexível e disposto a pensar um calendário diferente, mas é parte de um pacote [...] agora entraremos em uma etapa de análise para ver o que poderá ser repensado e o que deverá ser mantido" (BÜCHI..., 1998; ARANCELES: DIPUTADOS..., 1998; CHADWICK..., 1998). Mesmo próximo de se chegar a um acordo, o comportamento parlamentar continuava refratário à proposta, como ficou claro em carta assinada por 72 deputados - de um total de 120 enviada ao presidente da República para pedir modificações ao projeto original. Diante desde cenário, o governo, por meio do Ministério da Fazenda, comunicou, mais uma vez, a decisão de adiar o envio 
do projeto de lei ao Congresso, e de retirar a aplicação de "suma urgência", que desagradou, profundamente, os parlamentares.

Em meados de agosto, no entanto, após intensificação das negociações, Foxley declarou que os três eixos das demandas legislativas estavam sendo apreciados pelo Executivo: a questão da gradualidade, as medidas de proteção ao setor agrícola e as políticas de fomento para as PMEs (REBAJA DE ARANCELES, EN TIERRA..., 1998; MAPA..., 1998). Assim, o presidente da Comissão de Finanças do Senado, um dos principais negociadores da Concertación junto ao Executivo, disse acreditar que uma vez que os parlamentares analisassem a nova proposta, as chances de aprovação seriam grandes. Os dias que se seguiram foram fundamentais para o desfecho da negociação, pois o governo começou a fechar acordos com o grupo transversal e com parte da oposição.

Nas negociações com parlamentares da base governista que buscavam maior proteção ao setor agrícola, o governo comprometeu-se com as seguintes medidas: programas de recuperação e fertilização de solos; prorrogação da lei de fomento à irrigação, que expirava em agosto de 1999; formulação de um sistema de salva-guarda; manutenção do sistema de banda de precios; e aumento dos Fundos de Promoção às Exportações, administrado pela Direccion de Promoción de Exportaciones (ProChile). O anúncio fora feito pelo ministro da Agricultura, Carlos Mladinic, e pelo presidente da SNA, Ricardo Ariztía (RECURSOS..., 1998). Além do mais, ficou acertado que o sistema de reintegro simplificado, incompatível com normas da Organização Mundial do Comércio (OMC), seria instinto de forma gradual, e que uma parte do dinheiro iria para programas de ajuda às PMEs e a outra compensaria as perdas fiscais da desgravação. Por fim, chegou-se a um acordo a respeito da forma de aplicação da redução tarifária, que seria de um ponto percentual por ano. Todos os compromissos foram formalizados no Protocolo de Fomento Produtivo, acertado entre o governo e parlamentares (REPÚBLICA DE 
CHILE, 1998a; LOS US\$ 100 MILLONES..., 1998; RN EXIGE..., 1998; GOBIERNO ASEGURA..., 1998), o que permitiu que o projeto fosse avaliado de forma positiva na Comissão de Finanças e enviado ao plenário da Câmara dos Deputados, para ser aprovado por 55 votos a favor e 38 contra.

Com o projeto de lei sendo encaminhado para o segundo trâmite constitucional no Senado, outro protocolo foi assinado entre o governo e parlamentares. O Protocolo de Entendimiento Proyecto de Ley Rebaja Aranceles, subscrito pelos ministros Aninat, Mladinic e Lavalle (Economia) e por líderes dos partidos da Concertación e da Alianza ${ }^{24}$ estabeleceu, de forma mais detalhada, os termos do acordo entre o Legislativo e o governo (REPÚBLICA DE CHILE, 1998b). ${ }^{25}$

Definidos e confirmados os compromissos do Executivo com a agricultura tradicional e com as PMEs, e, mais importante, uma vez dilatado o prazo para a implementação da redução tarifária, em razão da opção de queda de um ponto percentual por ano, o Senado aprovou a medida por 26 votos a favor, contra cinco. O projeto ainda retornou à Câmara, pois houve modificações pontuais inseridas na tramitação no Senado. Após três anos de negociações, a Lei $\mathrm{n}^{\mathrm{o}} 19.589$ foi sancionada pelo presidente Frei no final de outubro e entrou em vigor em 15 de novembro.

Tendo como base a proposta inicial do governo, apresentada pelo ministro Aninat e divulgada pela imprensa no mês de março, conforme se pode averiguar no Quadro 1, houve alterações substanciais durante as negociações com a bancada governista, com a oposição e com a iniciativa privada. Um elemento capaz de apresentar a dimensão da complexidade da questão pode ser o número de vezes que o Executivo decidiu postergar o envio do projeto de lei para o Congresso Nacional em razão do risco de ver a proposta rechaçada: foram quatro vezes entre março e agosto. Vale ressaltar, também, que, ape- 


\section{Flávio Leão Pinheiro}

\section{Quadro 1}

Comparação das Propostas, das Demandas e do Resultado Final das Negociações para a Aprovação da Lei $n^{\circ} 19.589 *$

\begin{tabular}{|c|c|c|c|c|}
\hline $\begin{array}{l}\text { Origem da } \\
\text { Proposta }\end{array}$ & $\begin{array}{l}\text { Propostas do } \\
\text { Executivo em } \\
\text { Março }\end{array}$ & $\begin{array}{l}\text { Propostas do } \\
\text { Executivo em } \\
\text { Maio }\end{array}$ & $\begin{array}{l}\text { Demandas de } \\
\text { Parlamentares }\end{array}$ & $\begin{array}{l}\text { Protocolos de } \\
\text { Entendimento e } \\
\text { Lei no } 19.589\end{array}$ \\
\hline Desgravação (\%) & $3 \%$ & $5 \%$ & $5 \%$ & $5 \%$ \\
\hline Implementação & Imediata & Gradual, $3+1+1$ & $\begin{array}{l}\text { Gradual, um ponto } \\
\text { por ano }\end{array}$ & $\begin{array}{l}\text { Gradual, um ponto } \\
\text { por ano }\end{array}$ \\
\hline Amplitude & $\begin{array}{l}\text { Aplicação } \\
\text { uniforme }\end{array}$ & & $\begin{array}{l}\text { Discriminação de } \\
\text { lista de produtos } \\
\text { sensíveis }\end{array}$ & $\begin{array}{l}\text { Sem } \\
\text { discriminação, } \\
\text { mas com Lei de } \\
\text { Salvaguardas e } \\
\text { manutenção de } \\
\text { banda de precios }\end{array}$ \\
\hline $\begin{array}{l}\text { Compensações } \\
\text { para Setores } \\
\text { Sensíveis }\end{array}$ & $\begin{array}{l}\text { Sem } \\
\text { compensação } \\
\text { para setores } \\
\text { sensíveis }\end{array}$ & & $\begin{array}{l}\text { Compensação } \\
\text { para setores } \\
\text { sensíveis }\end{array}$ & $\begin{array}{l}\text { Compensações } \\
\text { para Agro e para } \\
\text { PMEs }\end{array}$ \\
\hline $\begin{array}{l}\text { Compensações } \\
\text { Fiscais }\end{array}$ & $\begin{array}{l}\text { Compensação } \\
\text { fiscal (US\$ } 420 \\
\text { mi.) }\end{array}$ & & - & \\
\hline
\end{tabular}

* Este quadro foi montado com informações retiradas de todas as matérias do La Tercera citadas anteriormente.

sar da iniciativa sobre a matéria ser de competência exclusiva do presidente, o Legislativo teve uma parcela considerável de responsabilidade na ação do Executivo, pois a implementação da abertura unilateral foi uma das condições impostas pelos legisladores durante as negociações do ACE-35. Assim, no que diz respeito ao segundo programa de abertura unilateral, estabelecido por meio da Lei n ${ }^{0}$ 19.589, em 1998, a instituição legislativa teve influência direta tanto na definição da agenda como em seu conteúdo.

\section{Conclusão}

À luz das hipóteses do aumento de poder do Legislativo e da sua influência, os estudos de caso acima apresentados indicam que o Poder Legislativo chileno detém capacidade para influenciar o processo 
decisório da política comercial. Os ACEs negociados com Argentina, México, Bolívia, Venezuela, Colômbia e Equador (ACE-16, ACE-17, ACE-22, ACE-23, ACE-24 e ACE-32, respectivamente), assim como a votação da Lei $\mathrm{n}^{\mathrm{O}} \mathrm{19} .065$, poderiam ser explicados por meio da hipótese da resignação, pois, dado que, à primeira vista, o Poder Legislativo teve uma posição marginal no processo, poder-se-ia presumir que a instituição teria se resignado frente ao Executivo, especialmente pelo fato de os acordos nem sequer terem tido trâmite legislativo. No entanto, em ocasiões semelhantes, o Congresso mostrou postura diferente, e procurou influenciar o processo decisório com o intuito de ter suas preferências atendidas, como ocorreu no caso do ACE-35, do ACE-38 e da Lei no ${ }^{19.589 . ~ A s s i m, ~ a ~ h i p o ́ t e-~}$ se em questão não seria capaz de explicar esse padrão de comportamento.

A hipótese do aumento de poder do Legislativo, portanto, é capaz de explicar melhor o comportamento da instituição legislativa no processo decisório da política comercial. No caso do ACE-35, a validade do postulado é evidente. Primeiro, tratava-se de matéria fora da área de competência do Legislativo; no entanto, por meio de intensa negociação, os parlamentares foram capazes de alterar um costume político e permitir que o ACE-35 tramitasse no Congresso. Ou seja, conseguiu-se institucionalizar a participação do Legislativo quando emergiram alguns pontos conflitantes com o Executivo. Em segundo lugar, o Congresso foi eficiente em negociar a implementação de políticas públicas compensatórias e obter o compromisso de um segundo programa de abertura unilateral, influindo no desfecho do processo. Ainda no caso do ACE-35, o Executivo foi incapaz de impedir que o Congresso Nacional influísse no processo decisório, manipulando as estruturas de participação, conforme informa a hipótese da influência.

No caso da negociação do ACE-38 entre Chile e Peru, segue-se o mesmo raciocínio. Apesar de não ter havido discordância substanti- 
va entre os interesses do Legislativo e do Executivo, havia, na verdade, um ambiente de instabilidade e insegurança sobre a entrada em vigor do acordo comercial. A intervenção do Legislativo foi justamente para evitar que um processo mais lento fosse instaurado, colocando em risco a própria consecução do ato. A manifestação do Congresso, portanto, serviu para explicitar que havia a convergência de interesses e que, dessa forma, não seria necessária revisão legislativa. Além do mais, negociações que se iniciaram durante o processo permitiram alterações na regra do processo decisório, atendendo aos interesses dos parlamentares.

Por fim, a avaliação da votação da Lei n⿳ํㅡㄹ 19.589 também configurou um momento em que o Legislativo influenciou na formatação da política comercial, alterando, substancialmente, o resultado final. A tramitação do projeto de lei da redução tarifária foi marcada por longa negociação entre e o Legislativo e o Executivo, e a intervenção legislativa alterou o calendário da implementação da medida e sua abrangência, estipulando compensações para determinados setores.

Diante do exposto, é perfeitamente razoável afirmar, portanto, que, mesmo restrito à atuação ex post, o Poder Legislativo chileno detém capacidade para influir no processo decisório da política comercial, uma vez que o Executivo leva em consideração as preferências da instituição antes de enviar matéria ao Congresso. Ademais, de acordo com os casos examinados, o Poder Executivo não foi capaz de deter a participação do Congresso. 


\section{Notas}

1. De forma objetiva, e incorrendo no risco da simplificação, pode-se dizer que elas são: a centralidade do Estado, a ênfase nas relações de poder e a percepção de que a anarquia é uma característica inerente à esfera internacional (MORGENTHAU, 1951; KENNAN, 1984; WALTZ, 1996).

2. Para se averiguar a existência de trabalhos específicos sobre o Legislativo chileno e política externa (e política comercial), utilizou-se como referências as seguintes fontes: a plataforma Cybertesis, que congrega mais de duas mil dissertações de Mestrado e teses de Doutorado (http://www.cybertesis.cl/) - Universidad de Chile (1350), Universidad Austral de Chile (397), Universidad de Concepción (102), Pontificia Universidad Católica (PUC) de Valparaíso (52) e Universidad del Bío-Bío (22); o sistema Scielo Chile (http://www.scielo.cl); a base de dados Proquest (http://www.proquest.com.br/); a Revista de Ciencia Política (1985-2006) (http://www.puc.cl/icp/revista/); o banco de artigos acadêmicos da Latin America Research Review (http://larr.lanic.utexas.edu/search/); além do banco de trabalhos da American Political Science Association (APSA) (http://www.apsanet.org/), entre 2002 e 2006, do International Studies Association (ISA) (http://www.isanet.org/), entre 2000 e 2006, e da Midwest Political Science Association (MPSA) (http://www.indiana.edu/ mpsa/). Nos sites que disponibilizavam sistema de busca, foram inseridos os seguintes termos: Chile, Chilean Politics, legislative politics, legislativo, Congreso, Congress, Camara de los Diputados, Senado/Chile, Chilean, foreign policy, política exterior/Chile, Chilean, trade policy e política comercial.

3. A expressão "processo de ratificação" deve ser interpretada em sentido amplo, pois se trata, tão-somente, da aceitação do acordo fechado no Nível I por atores políticos domésticos do Nível II (PUTNAM, 1988, p. 436).

4. Esta e as demais citações escritas originalmente em língua estrangeira foram livremente traduzidas para este artigo.

5. O mecanismo de police patrol oversight representa a atuação direta do Legislativo na fiscalização dos atos do Executivo e de suas agências, enquanto o mecanismo de fire alarm oversight é uma ação de forma descentralizada - ou talvez, menos ativa - por meio da atuação conjunta com outros atores políticos interessados. A distinção é feita em um contexto no qual se debatia a eficiência dos mecanismos de controle do Congresso norte-americano sobre o Executivo. McCubbins e Schwartz (1984, p. 166) argumentavam que, embora houvesse uma diminuição da atuação direta do Legislativo (police patrol), optou-se por um meio mais eficiente, uma atuação induzida por outros atores (fire alarm). Ou 


\section{Flávio Leão Pinheiro}

seja, a falta de police control oversight não representava perda de poder da instituição legislativa.

6. De fato, paralelo ao reconhecimento das limitações dos estudos produzidos durante a década de 1990, e especialmente em razão de estarem munidos de uma série temporal mais longa para ser analisada e de um maior número de legislaturas para serem comparadas, novos estudos, com o enfoque específico sobre a atividade parlamentar, começam a emergir. Exemplos são os trabalhos: sobre as comissões mistas (comisiones mixtas) do Congresso, elaborado por Alemán e Buitrago (2005); sobre os padrões de votação no Senado, de John Londregan (2000; 2002); sobre os métodos de escolhas de candidatos ao Congresso e sua relação com o Executivo, além de possíveis interferências deste, de Siavelis (2002); sobre a dinâmica da formação de coalizões, de Alemán e Saiegh (2006) e Carey (2002); ou sobre o poder de agenda e a relação entre Executivo e Legislativo, de Alemán (2003) e de Aninat e Londregan (2006).

7. Para os padrões latino-americanos, este número é considerado alto, pois a média regional está abaixo de $40 \%$. Isso poderia ser explicado pelo fato de que, no país, uma cadeira no Parlamento é o ápice da carreira política, uma vez que o Chile não é uma federação e a disputa pela administração provincial não compete com a busca de uma vaga no Parlamento, como ocorre, por exemplo, na Argentina e no Brasil.

8. De acordo com o artigo I, seção 8, o Congresso detém o poder de criar e coletar taxas, tarifas, impostos; de pagar as dívidas e de regular a defesa comum e o bem-estar geral dos Estados Unidos, além de regular o comércio com nações estrangeiras, e entre os demais estados.

9. A interpretação desse dispositivo afetou diretamente a capacidade institucional do Poder Legislativo sobre a política comercial do Chile no início dos anos 1990, porque fez com que um dos principais instrumentos de negociação do país - os Acordos de Complementação Econômica (ACEs), negociados no âmbito da Associação Latino-americana de Integração (Aladi) sob o marco jurídico do Tratado de Assunção de 1980 (TA-80) - não passasse pelo escrutínio do Congresso Nacional. Em decorrência da interpretação restritiva do art. 50 da Constituição, entendia-se que os ACEs não precisavam da ratificação, uma vez que o tratado em vigor seria TA-80 e eles teriam a mera função de dar cumprimento ao acordo-marco.

10. Além do mais, a reforma constitucional introduzida pela Lei 20.050 acrescentou sete parágrafos ao antigo art. 50. Em relação à questão da regulação e implementação de tratados-marco, manteve-se a idéia original presente no $\mathrm{n}^{\circ} 1$ anterior, permitindo que tratados que não abordem matérias de lei sejam internalizados por meio de decreto, sem apreciação do Poder Legislativo. Assim, com 
intuito de extinguir as ambigüidades do texto, adicionou-se o seguinte trecho: "Não será requerida a aprovação do Congresso no caso de tratados celebrados pelo presidente da República no exercício de seu poder regulatório" (CHILE, 2003). O segundo ponto que merece destaque diz respeito à obrigatoriedade de o Executivo informar ao Congresso o conteúdo dos tratados antes de assiná-los. Dessa forma, o Congresso poderá pôr em prática outra atribuição: apresentar reservas e declarações interpretativas acerca dos tratados assinados pelo Executivo, considerado por muitos um avanço. O texto aponta que a instituição poderá "sugerir" reservas, de forma que não será obrigatório acatá-las. Por fim, definiu-se o quorum necessário para aprovação de tratado internacional, que deverá seguir as regras estabelecidas no art. 66. As demais modificações dizem respeito a procedimentos de derrogação, suspensão e modificação dos tratados.

11. Esse mecanismo foi criado sob marco jurídico do Tratado de Assunção de 1980 (TA-80), que deu origem à Aladi. Seguindo os princípios norteadores da Aladi, de promover a integração regional de forma gradual e prezando pela flexibilidade dos compromissos comerciais, os ACEs foram idealizados para permitir que os países signatários pudessem ir além das metas estabelecidas, e aprofundassem a integração de forma bilateral ou sub-regional, mas deixando sempre espaço para a adesão negociada de outros países-membros.

12. ACE-16, decreto 1495/1991; ACE-17, decreto 1569/1991; ACE-22, decreto 402/1993; ACE-23, decreto 421/1993; ACE-24, decreto 1535.

13. De forma resumida, previa-se no acordo a criação de uma zona de livre-comércio em dez anos, mediante a adoção de um programa de liberalização comercial aplicável aos produtos originários dos territórios dos países signatários. As desgravações tarifárias eram progressivas e automáticas. A partir de $1^{\circ}$ de outubro de 1996, 90\% dos produtos comercializados entre as partes já entrariam neste processo. Entretanto, o comércio de produtos agrícolas e de veículos automotores, além de uma lista de produtos sensíveis e doze anexos contendo exceções, passariam por processo de desgravação diferenciado (Aladi, ACE-35).

14. À época, a coalizão governista detinha 21 cadeiras $(46,8 \%)$; a oposição, $26(55,3 \%)$. Vale ressaltar que, ao cálculo do número de senadores da oposição, somam-se os senadores designados, que, na maioria das vezes, acompanham o voto desta bancada (SIAVELIS, 2000; LONDREGAN, 2000).

15. Especialmente, o aumento de produtos na lista de exceções.

16. Os parlamentares trataram de informar que o ACE-35 não era, simplesmente, uma implementação do TA-80; que não foi assinado pelas mesmas par- 


\section{Flávio Leão Pinheiro}

tes do TA-80, já que o Mercosul é pessoa jurídica e não é signatário do acordo-marco; e que aborda matérias que só podem ser reguladas por lei ordinária.

17. Em coletiva à imprensa concedida pelos ministros da Fazenda, Eduardo Aninat, da Agricultura, Emiliano Ortega, e pelo presidente do Banco do Estado, Andrés Sanfuentes, para o lançamento de linha de crédito de US\$ 100 milhões para o setor, foi reafirmado que o governo se limitaria a programas de incentivo à agricultura, mas que não estava disposto a aplicar medidas compensatórias, tal como a oposição havia proposto.

18. De forma resumida, o ACE-38 contemplou a desgravação de todo o comércio bilateral. De imediato, 2.600 produtos, 37,5\% do total da pauta de itens comercializados entre os dois países, atingiram 0\%. Outros 2.440 itens (ou $17 \%$ de produtos da pauta bilateral) atingiriam a liberalização em cinco anos. $\mathrm{O}$ restante ficou dividido entre três listas, com liberalização total prevista para dez anos (729 itens/10,5\%), quinze anos (270 itens/3,9\%) e dezoito anos (24 itens $/ 0,3 \%$ ). Além do mais, o acordo previa o estabelecimento de cláusula de salva-guarda e deixou as portas abertas para avanços no setor de serviços e para o estabelecimento de mecanismo de proteção de investimentos. Durante as negociações, a maior parte das críticas adveio da indústria têxtil, mas, no geral, o acordo foi bem recebido pelo setor privado, não havendo oposição doméstica organizada, apenas críticas dispersas daqueles que esperavam maior abertura da economia peruana (DIPUTADOS..., 1998).

19. Os senadores Jorge Pizarro (PDC) e Hernán Larraín (UDI), bem como o deputado Edgardo Riveros (PDC), censuraram a demanda publicamente (DIPUTADOS..., 1998).

20. Por parte dos governistas, assinaram o protocolo de acordo os deputados Jocelyn-Holt (PDC), Andrés Palmas (PDC) e Gabriel Ascencio (PDC); entre os membros da Alianza, Rodrigo Alvarez (UDI), Gustavo Alessandri (RN) e Arturo Longton ( $\mathrm{RN})$.

21. Vale ressaltar que essa redução tarifária diz respeito, tão-somente, ao imposto de importação. Outros impostos que atuam sobre os produtos importados, como, por exemplo, o Imposto sobre Valor Agregado (IVA), que é de 18\% sobre o valor do bem, não foram atingidos.

22. Com base nos dados fornecidos pelo Sistema de Tramitación de Proyectos del Congreso Nacional (http://sil.senado.cl/pags/index.html), não foi possível ter acesso ao resultado das votações na Câmara dos Deputados e no Senado, pois problemas técnicos impedem a leitura das sessões parlamentares.

23. Manuel Antonio Matta (PDC), Marco Cariola (sem partido), Gabriel Valdés (PDC), Hosáin Sabag (PDC), Sergio Páez (PDC), Jorge Lavandero (PDC), 
Rafael Moreno (PDC), Sergio Diez (RN), Antonio Horvath (sem partido), Hernán Larraín (UDI), Andrés Chadwick (UDI), Rodolfo Stange (sem partido), Sergio Fernández (UDI), Jaime Gazmuri (PS), José Antonio Viera-Gallo (PS), Francisco Prat (RN), Francisco Javier Errázuriz (União de Centro Centro UCC), Marco Cariola (UDI), Sergio Romero (RN), Mario Ríos, Mariano Ruiz-Esquide e Roberto Muñoz.

24. Os signatários foram: Edgardo Boeninger (PDC), Marco Cariola (UDI), Fernando Cordero (Institucional), Sergio Díez Urzúa (RN), Alejandro Foxley (PDC), Jaime Gazmuri (PS), Hernán Larraín (UDI), Ricardo Núñez (PS), Carlos Ominami (PS), Augusto Parra (Institucional), Jorge Pizarro (PDC), Sergio Romero (RN), Enrique Silva (Partido Revolucionário Social-Democrata PRSD), Rodolfo Stange (UDI), Ramón Vega (sem partido) e Andrés Zaldívar (PDC).

25. Uma vez aprovada a Ley de Rebaja de Aranceles, seria enviado ao Congresso um projeto de lei de salvaguardas, compatível com as normas do General Agreement on Tariffs and Trade (GATT) e da OMC, até o dia 6 de outubro de 1998. Além do mais, haveria a prorrogação da Lei de Fomento à Irrigação (Lei $n^{\circ}$ 18.450), por um prazo de dez anos, e a aprovação de lei para garantir a implementação de programa para recuperação de solos degradados, no qual seriam aportados, no mínimo, US\$ 90 milhões anuais, a partir de 2001. Em caráter complementar ao acordo firmado em 1996, no qual o Executivo se comprometeu a repassar US\$ 500 milhões ao setor agrícola, estabeleceu-se um novo cronograma: em 1999, US\$ 17 milhões; em 2000, US\$ 45 milhões; em 2001, US\$ 50 milhões, que serão renovados nos anos seguintes. Esses recursos serão aportados sob a forma de programas de apoio, compatíveis com as normas da OMC; em relação às PMEs, a Corfo seria responsável pelo repasse de dois terços dos recursos que eram aplicados no sistema de reintegro simplificado, e que agora serão destinados a programas de fomento e apoio às PMEs. O cronograma de repasse dos recursos também foi definido: US\$ 10 milhões em 1999, US\$ 20 milhões em 2000, US\$ 30 milhões em 2001, US\$ 40 milhões em 2002 e US\$ 67 milhões em 2003, que serão renovados nos anos seguintes. 
ACUERDO con Perú no se tramita en Parlamento. La Tercera, Santiago, 8 jul. 1998. Disponível em: <http://www.latercera.cl/medio/articulo/0,0,3255_5664_9523888,00.html>. Acesso em: 7 fev. 2008.

ALEMÁN, Eduardo. Legislative rules and the amending process in Argentina, Chile and Mexico. In: ENCONTRO ANUAL DA AMERICAN POLITICAL SCIENCE ASSOCIATION (APSA), Filadélfia, 28-31 ago. 2003.

; BUITRAGO, Mónica Pachón. Congressional procedures and the proposer's advantage: how conference committees affect legislative outcomes in Chile and Colombia. In: CONFERÊNCIA DE ESTUDOS LATINO-AMERICANAS DA TEXAS A\&M UNIVERSITY, Las Vegas, 7-10 out. 2005.

ALEMÁN, Eduardo; SAIEGH, Sebastián M. Legislative preferences, political parties, and coalition unity in Chile. Comparative Politics, v. 39, n. 3, 2006.

ALTA tension en el Congreso. El Mercurio, Santiago, Política y Sociedad, p. P12, 10 sept. 1996.

ANINAT, Cristóbal; LONDREGAN, John. Measuring spatial aspects of legislative delay: evidence from the Chilean Congress. Center on Institutions and Governance Working Paper, n. 26, 2006. Disponível em: <http://igov.berkeley.edu/workingpapers/series2/No26_Londregan.pdf $>$. Acesso em: 3 out. 2007.

; NAVIA, Patricio; VIAL, Joaquín. Political institutions, policymaking processes, and policy outcomes in Chile. Research Network Working Paper, Washington, Inter-American Development Bank, no R-521, Feb. 2004. Disponível em: <http://www.iadb.org/publications/search.cfm?Topics=ET\&language $=$ English $\&$ searchLang $=\mathrm{E}>$.

APROBADA la asociasion con el Mercosur. El Mercurio, Santiago, Primera Página, p. A01, 11 sept. 1996.

ARANCELES: 17 senadores piden excluir de rebaja a productos agrícolas sensibles. La Tercera, Santiago, 23 jul. 1998. Disponível em: <http://www.latercera.cl/medio/articulo/0,0,3255_5676_9510570,00.html>. Acesso em: 7 fev. 2008. 
Poder Legislativo e Política Externa: Um

Estudo sobre a Influência do Congresso...

ARANCELES: DIPUTADOS le "pasan la cuenta" a Aninat. La Tercera, Santiago, 8 agosto 1998. Disponível em: <http://www.latercera.cl/medio/articulo/0,0,3255_5676_9517041,00.html>. Acesso em: 7 fev. 2008.

ARANCELES: OPOSICIÓN por compensación parcial. La Tercera, Santiago, 16 marzo 1998. Disponível em: <http://www.latercera.cl/medio/articulo/0,0,3255_5676_9568792,00.html>. Acesso em: 7 fev. 2008.

BÜCHI a favor de rebaja rápida y pareja. La Tercera, Santiago, 08 agosto 1998. Disponível em: <http://www.latercera.cl/medio/articulo/0,0,3255_5676_9517053,00.html>. Acesso em: 7 fev. 2008.

CAREY, John M. Parties, coalitions, and the Chilean Congress in the 1990s. In: MORGENSTERN, S.; NACIF, B. (Org.). Legislative politics in Latin America. Cambridge: Cambridge University Press, 2002.

; BALDEZ, Lisa. Budget procedure and fiscal restrain in post-transition Chile. In: HAGGARD, S.; MCCUBBINS, M. D. (Org.). Presidents, parliaments, and policy. Cambridge: Cambridge University Press, 2001.

CAREY, John M.; SHUGART, Matthew S. Presidents and assemblies constitutional design and electoral dynamics. Cambridge: Cambridge University Press, 1992.

CHADWICK: "Ejecutivo se acerca a nosotros cuando le conviene". La Tercera, Santiago, 8 agosto 1998. Disponível em: <http://www.latercera.cl/medio/articulo/0,0,3255_5664_9516687,00.html>. Acesso em: 7 fev. 2008.

CHILE. Constitución política de La República de Chile. Santiago: Editorial Juridica de Chile, 2003.

COLLIER, Simon; SATER, Willian F. Historia de Chile: 1808 - 1994. Madrid: Cambridge University Press, 1999.

CONGRESO Nacional pide tramite legislativo. El Mercurio, Santiago, Revista del Campo, p. A02, 8 abr. 1996.

CONSENSO parlamentario: medida sobre el Mercosur es acertada. EI Mercurio, Santiago, El País, p. C02, 25 mayo 1996.

COX, Gary W.; MORGENSTERN, Scott. Latin America's reactive assemblies and proactive presidents. In: MORGENSTERN, S.; NACIF, B. Legislative politics in Latin America. Cambridge: Cambridge University Press, 2002. 
DIPUTADOS retiran recurso del Tribunal Constitucional. La Tercera, Santiago, 22 agosto 1998. Disponível em: <http://www.latercera.cl/medio/articulo/0,0,3255_5664_9502560,00.html>. Acesso em: 7 fev. 2008.

EL CONGRESO decidira pacto con Mercosur. El Mercurio, Santiago, Primera Página, p. A01, 25 mayo 1996.

FREI prometió pronto envío de rebaja arancelaria. La Tercera, Santiago, 13 marzo 1998. Disponível em: <http://www.latercera.cl/medio/articu1o/0,0,3255_5676_9587458,00.html>. Acesso em: 7 fev. 2008.

FREI RUIZ-TAGLE, Eduardo. Mensagem presidencial ao Congresso Nacional do Chile no início da legislatura. Santiago, 21 mai. 1998. Disponível em: $<$ http://www.bcn.cl/susparlamentarios/mensajes_presidenciales/presi98.pdf $>$.

GERNER, Deborah J. The evolution of the study of foreign policy. In: NEACK, L.; HEY, J. A. K.; HANEY, P. J. (Org.). Foreign policy analysis: continuity and change in its second generation. New Jersey: Prentice Hall, 1995.

GOBIERNO ASEGURA votos para rebaja de aranceles. La Tercera, Santiago, 19 agosto 1998. Disponível em: <http://www.latercera.cl/medio/articulo/0,0,3255_5676_9500926,00.html>. Acesso em: 7 fev. 2008.

GOBIERNO DEFINIÓ prioridades legislativas. La Tercera, Santiago, 21 agosto 1998. Disponível em: <http://www.latercera.cl/medio/articulo/0,0,3255_5664_9502352,00.html>. Acesso em: 7 fev. 2008.

GOBIERNO SE COMPROMETIO a bajar aranceles. El Mercurio, Santiago, Primera Página, p. A01, 10 sept. 1996.

HILL, Christopher; LIGHT, Margot. Foreign policy analysis. In: LIGHT, M.; GROOM, A. J. R. (Org.). International relations: a handbook of current theory. London: Pinter Publishers, 1985.

HUNEEUS, Carlos; BERRÍOS, Fabiola. El Congreso Nacional en un régimen presidencial: el caso de Chile. Revista de Derecho Público, v. 66, p. 61-97, 2003.

JONES, Mark P. Electoral laws and the survival of presidential democracies. Notre Dame: University of Notre Dame Press, 1995.

KENNAN, George F. American diplomacy 1900-1950. Chicago: University of Chicago Press, 1984. 
Poder Legislativo e Política Externa: Um

Estudo sobre a Influência do Congresso...

LANZARO, Jorge. Tipos de presidencialismo y modos de gobierno en América Latina. In: LANZARO, J. (Org.). Tipos de presidencialismo y coaliciones políticas en América Latina. Buenos Aires: Clacso, 2001.

LINZ, Juan J. Presidential or parliamentary democracy: does it make a difference?. In: VALENZUELA, A.; LINZ, J. J. (Org.). The failure of presidential democracy. Baltimore: Johns Hopkins University Press, 1994.

LONDREGAN, John. Legislative institutions and ideology in Chile. Cambridge: Cambridge University Press, 2000.

Appointment, reelections, and autonomy in the Senate of Chile. In: MORGENSTERN, S.; NACIF, B. (Org.). Legislative politics in Latin America. Cambridge: Cambridge University Press, 2002.

LOS US\$ 100 MILLONES extras para pymes y agro. La Tercera, Santiago, 18 ago. 1998. Disponível em: <http://www.latercera.cl/medio/articulo/0,0,3255_5676_9500767,00.html>. Acesso em: 7 fev. 2008.

LOS VAIVENES de la “operación Mercosur”. El Mercurio, Santiago, Economía y Negocios. Enfoques, p. B08, 15 set. 1996.

MAINWARING, Scott; SHUGART, Matthew Soberg. Juan Linz, presidentialism, and democracy: a critical appraisal. Working Paper, Kellogg Institute, n. 200, 1993. Disponível em: <http://kellogg.nd.edu/publications/workingpapers/namerica.shtml>. Acesso em: 3 out. 2007.

. Presidentialism and democracy in Latin America: rethinking the terms of the debate. In: ; SHUGART, M. S. Presidentialism and democracy in Latin America. Cambridge: Cambridge University Press, 1997a.

. Presidentialism and the party system. In: ; SHUGART, M. S. Presidentialism and democracy in Latin America. Cambridge: Cambridge University Press, 1997b.

MAPA actualizado de las bancadas transversales: sus integrantes e intereses. La Tercera, Santiago, 10 agosto 1998. Disponível em: <http://www.latercera.cl/medio/articulo/0,0,3255_5664_9516728,00.html>. Acesso em: 7 fev. 2008.

MARTIN, Lisa. Democratic commitments - legislatures and international cooperation. Princeton: Princeton University, 2000. 
MCCUBBINS, Mathew. Abdication or delegation? Congress, the bureaucracy, and the delegation diemma. Regulation, v. 22, n. 2, p. 150-175, 1999.

; LUPIA, Arthur. Representation or abdication? How citizens use institutions to help delegation succeed. European Journal of Political Research, v. 37, n. 3, p. 291-307, 2000.

MCCUBBINS, Mathew; SCHWARTZ, Thomas. Congressional oversight overlooked: police patrols vs. fire alarms. American Journal of Political Science, v. 28, n. 1, p. 165-179, 1984.

MEDINA, Ibaceta M. Las funciones del Congreso Nacional en materias internacionales en el constitucionalismo chileno. Revista de Derecho Público, v. 65, p. 234-254, 2003.

MILNER, Helen V. Interests, institutions and information - domestic politics and International Relations. Princeton: Princeton University Press, 1997.

MONTECINOS, Verónica. Economic policy making and parliamentary accountability in Chile. United Nations Research Institute for Social Development Paper, n. 11, 1ำ dez. 2003. Disponível em: <http://www.unrisd.org/ UNRISD/website/document.nsf/(httpPublications)/AFA3585F2764 BF98C1256F010023B686?OpenDocument>. Acesso em: 3 out. 2007.

MORGENSTERN, Scott. Towards a model of Latin American legislature. In: ; NACIF, B. (Org.). Legislative politics in Latin America. Cambridge: Cambridge University Press, 2002a.

Explaining legislative politics in Latin America. In: ; NACIF, B. (Org.). Legislative politics in Latin America. Cambridge: Cambridge University Press, 2002b.

MORGENTHAU, Hans J. In defense of the national interest. New York: Alfred A. Knopf, 1951.

NAVIA, Patricio; HEISS, Claudia. You win some and you lose some: civil-military trade-offs in Chile's transition to democracy. In: ENCONTRO ANUAL DA AMERICAN POLITICAL SCIENCE ASSOCIATION (APSA), Filadélfia, 28-31 ago. 2003.

NO HAY plan compensatorio por Mercosur. EI Mercurio, Santiago, Primera Página, p. A01, 24 jul. 1996. 
NOLTE, Detlef. El Congreso Chileno y su aporte a la consolidación democrática en perspectiva comparada. Revista de Ciencia Política, v. 23, n. 2, p. 43-67, 2003.

O’DONNELL, Guillermo. Delagative democracy? Working Paper, Kellogg Institute, n. 172, Mar. 1992. Disponível em: <http://kellogg.nd.edu/publications/workingpapers/WPS/172.pdf>. Acesso em: 3 out. 2007.

On the State, democratization and some conceptual problems. Working Paper, Kellogg Institute, n. 192, Apr. 1993. Disponível em: <http://www.nd. edu/ kellogg/publications/workingpapers/WPS/192.pdf>.

PACTO verbal del gobierno y SNA para desarrollo agricola. El Mercurio, Santiago, Economía y Negocios, p. 1, 17 sept. 1996.

PARLAMENTARIOS solicitan mas incidencia en RR.EE. EI Mercurio, Santiago, El País, p. C04, 8 abr. 1996.

PORRAS, José Ignacio. La estrategia chilena de acuerdos comerciales: un análisis político. Serie Comercio Internacional Cepal, n. 36, Dec. 2003. Disponível em: <http://www.cepal.org/cgi-bin/getProd.asp?xml=/publicaciones/xml/7/14247/P14247.xml\&xsl=/comercio/tpl/p9f.xsl\&base=/ tpl/top-bottom.xslt>. Acesso em: 3 out. 2007.

PRESUPUESTO de agricultura para el proximo año: US\$ 75 millones adicionales entregara gobierno al agro. El Mercurio, Santiago, Economía y Negócios, p. B01, 26 oct. 1996.

PROYECTO de aranceles va la próxima semana a La Moneda. La Tercera, Santiago, 14 marzo 1998. Disponível em: <http://www.latercera.cl/medio/articulo/0,0,3255_5676_9587872,00.html>. Acesso em: 7 fev. 2008.

PUTNAM, Robert D. Diplomacy and domestic politics: the logic of two-level games. International Organization, v. 42, n. 3, p. 427-460, 1988.

REBAJA DE ARANCELES, EN TIERRA derecha. La Tercera, Santiago, 10 agosto 1998. Disponível em: <http://www.latercera.cl/medio/articulo/0,0,3255_5676_9516964,00.html>. Acesso em: 7 fev. 2008.

"REBAJA DE ARANCELES SERÁ plenamente compensada". La Tercera, Santiago, 15 marzo 1998. Disponível em: <http://www.latercera.cl/medio/articulo/0,0,3255_5676_9568707,00.html>. Acesso em: 7 fev. 2008. 
RECURSOS adicionales para el agro. La Tercera, Santiago, 13 agosto 1998. Disponível em: <http://www.latercera.cl/medio/articulo/0,0,3255_5676_9518007,00.html>. Acesso em: 7 fev. 2008.

RN EXIGE que programas para el agro y las Pymes sean ley. La Tercera, Santiago, 18 agosto 1998. Disponível em: <http://www.latercera.cl/medio/articulo/0,0,3255_5676_9500755,00.html>. Acesso em: 7 fev. 2008.

REPÚBLICA DE CHILE. Diario de sesiones del Senado. Publicación oficial. Legislatura 332ª , extraordinaria. Sesión 51 en martes 16 de abril de 1996. Santiago: Sistema de Tramitación de Proyectos del Congreso Nacional, 1996a. Disponível em: <httpsil.senado.cldocsildiar2049.doc>. Acesso em: 28 jan. 2008.

Diario de sesiones del Senado. Publicación oficial. Legislatura 333aㅡ, ordinaria. Sesión 38 lunes 9 de septiembre de 1996. Santiago: Sistema de Tramitación de Proyectos del Congreso Nacional, 1996b. Disponível em: <http://sil.senado.cl/docsil/diar2427.doc>. Acesso em: 28 jan. 2008.

Informe de la Comisión de Hacienda recaido en el proyecto de ley que rebaja la tasa de los aranceles a las importaciones e introduce modificaciones a otras normas tributarias y económicas. Boletín no 2.218-05. Santiago: [s.n.], 1998a. Disponível em: <http://sil.senado.cl/docsil/info714.doc>. Acesso em: 26 jan. 2008.

Diario de sesiones del Senado. Publicación oficial. Legislatura 338ª , ordinaria. Sesión 31 a , en miércoles 16 de septiembre de 1998. Santiago: Sistema de Tramitación de Proyectos del Congreso Nacional, 1998b. Disponível em: $<$ http://sil.senado.cl/docsil/diar2896.doc>. Acesso em: 28 jan. 2008.

SAIEGH, Sebastian. The role of legislatures in the policymaking process. In: SEMINÁRIO ORGANIZADO PELO BANCO INTER-AMERICANO DE DESENVOLVIMENTO SOBRE REFORMA DO ESTADO, Washington, 28 fev.-2 mar. 2005.

SENADO estudiara la ratificacion del acuerdo. El Mercurio, Santiago, El País, p. C02, 26 marzo 1996.

SENADORES amenazan con rechazar rebaja arancelaria. La Tercera, Santiago, 12 jun. 1998. Disponível em: <http://www.latercera.cl/medio/articulo/0,0,3255_5676_9543273,00.html>. Acesso em: 7 fev. 2008.

SE POSTERGA proyecto de aranceles en busca de consenso político. La Tercera, Santiago, 28 jul. 1998. Disponível em: <http://www.latercera.cl/medio/articulo/0,0,3255_5676_9512430,00.html>. Acesso em: 7 fev. 2008. 
SIAVELIS, Peter M. The president and Congress in post-authoritarian Chile - institutional constraints to democratic consolidation. Pennsylvania: The Pennsylvania University Press, 2000.

The hidden logic of candidate selection for Chilean parliamentary elections. Comparative Politics, v. 34, n. 2, p. 419-438, 2002.

Accommodating informal institutions and Chilean democracy. In: ENCONTRO ANUAL DA AMERICAN POLITICAL SCIENCE ASSOCIATION, Washington, set. 2005.

SMITH, Steve. Theories of foreign policy: a historical overview. Review of International Studies, v. 12, n. 1, p. 13-29, 1986.

STEIN, Ernesto; TOMMASI, Mariano; ECHEBARRÍA, Koldo; LORA, Eduardo; PAYNE, Mark. The politics of policies-economic and social progress in Latin America. Cambrige: Harvard University Press; Inter-American Development Bank, 2006.

TRATADOS internacionales. El Mercurio, Santiago, Editorial, p. A03, 30 marzo 1996.

TSEBELIS, George; ALEMÁN, Eduardo. Presidential conditional agenda setting power in Latin America. World Politics, v. 57, n. 3, p. 396-420, 2005.

VALENZUELA, Arturo. The crisis of presidencialism in Latin America. In: MAINWARING, S.; VALENZUELA, A. Politics, society, and democracy Latin America. Boulder: Westview Press, 1998.

WALTZ, Kenneth. International politics is not foreign policy. Security Studies, v. 6, n. 1, p. 54-57, 1996. 


\section{Resumo}

\section{Poder Legislativo e Política Externa: Um Estudo sobre a Influência do Congresso Nacional do Chile na Formulação da Política Comercial durante a Década de 1990}

O senso comum indica que temas relacionados à política externa estão restritos ao Poder Executivo. Essa percepção aumenta quando diz respeito aos países latino-americanos. O objetivo deste trabalho, portanto, é questionar o senso comum, e averiguar se o Poder Legislativo chileno influencia no processo decisório da política externa, apesar de contar com mecanismos institucionais pouco sofisticados - somente a atuação ex post. O trabalho baseia-se na análise da atuação do Congresso Nacional na formulação da política comercial, tendo como estudo de caso as negociações dos Acordos de Complementação Econômica (ACE), que o Chile assinou durante a década de 1990, e as negociações das duas votações de redução de tarifas, ocorridas em 1991 e em 1998. Os resultados da pesquisa apontam que o Poder Legislativo é ator político relevante e capaz de influenciar o processo de formulação da política comercial.

Palavras-chave: Política Externa - Política Comercial - Poder Legislativo - América Latina - Chile

\section{Abstract}

\section{Congress and Foreign Policy: A Study on the Influence of the Chilean Congress on the Policy-Making Process of Trade Policy during the 1990's}

Conventional wisdom tells us that foreign policy-making is, normally, restricted to the Executive, a trend especially noticeable when in regard to Latin America. The aim of this essay, therefore, is to question such assumption, even thought the Chilean Legislature has at its disposal week institutional capacity - ex post control. The argument is based on a thorough 
Poder Legislativo e Política Externa: Um

Estudo sobre a Influência do Congresso...

analysis of the Chilean Congress while dealing with trade policy, during the negotiations of the Economic Complementarity Agreements (ECA), undersigned by Chile during the 1990s, and on the discussions of tariff reductions, voted in 1991 and 1998. The research attempts to appoint the Legislative Branch as a relevant political actor, capable of influencing the policy-making of trade policy.

Keywords: Foreign Policy - Trade Policy - Congress - Latin America Chile 